\title{
BROMO MOESIACAE-STIPETUM EPILOSAE - A NEW ASSOCIATION FROM THE RELICT MOUNTAIN STEPPE VEGETATION IN SOUTH- WESTERN BULGARIA
}

\author{
Salza TODOROVA ${ }^{1} \&$ Rossen TZONEV ${ }^{2}$
}

\begin{abstract}
A syntaxonomical analysis of the dry grasslands (Festuco-Brometea) in Bosnek karst region, Mt Vitosha (SW Bulgaria) has been carried out. These grasslands are part of the intrazonal vegetation distributed within the belts of xerophilous oak and mesophilous beech forest in the south-western foothills of the mountain. The bedrock is carbonate, the soils are dry and shallow, climate - moderate continental. This vegetation grows mostly on steep slopes, with southern and south-western exposition. Apart from the typical for Festuco-Brometea calcicoles, the studied vegetation is characterized by many endemic (regional and local) species and at the same time includes a lot of Mediterranean species. As a result of the analysis, a new association, Bromo moesiacae-Stipetum epilosae ass. nova, has been established that belongs to the alliance Saturejon montanae. A comparison with related syntaxa from other karst mountains from SW Bulgaria and E Serbia is made, and some conclusions about the origin of the steppe vegetation in that region are drawn.
\end{abstract}

Keywords: calcareous grasslands, dry grasslands, phytosociology, syntaxonomy, Festuco-Brometea, Saturejon montanae.

\section{Izvleček}

Naredili smo sintaksonomsko analizo suhih travnikov (Festuco-Brometea) v kraškem območju Bosnek v gorovju Vitoša (jugozahodna Bolgarija). Ti travniki so del intraconalne vegetacije, razširjene v pasu kserofilnih hrastovih in mezofilnih bukovih gozdov na jugozahodnih vznožjih hribovja. Matična podlaga je karbonatna, tla so suha in plitva, podnebje je zmerno celinsko. Vegetacija uspeva na strmih naklonih z južno in jugozahodno ekspozicijo. Poleg značilnih vrst razreda Festuco-Brometea označujejo preučevano vegetacijo številne endemične (regionalne in lokalne) vrste in številne sredozemske vrste. Kot rezultat smo opisali novo asociacijo Bromo moesiacae-Stipetum epilosae ass. nova, ki jo uvršč amo v zvezo Saturejon montanae. Naredili smo tudi primerjavo s sorodnimi sintaksoni s kraških gorovij jugozahodne Bolgarije in vzhodne Srbije in podali nekaj zaključkov o izvoru stepske vegetacije v preučevanem območju.

Ključne besede: apnenčasti travniki, suhi travniki, fitosociologija, sintaksonomija, Festuco-Brometea, Saturejon montanae.

\section{INTRODUCTION}

The Bosnek karst region (Mt Vitosha, SW Bulgaria) is the only site on the mountain built up from calcareous bedrock and covered, even though partially, by steppe vegetation. Surprisingly, up to now it has not been explored from a phytosociological point of view, although quite a few similar phytocoenoses have been described from other low-hilly mountains in the same region (SW Bulgaria): Dragoman region (Velchev 1962), Mt Golo bardo (Apostolova-Stoyanova et al. 2005) and Mt Lozenska (Pedaschenko et al. 2009) (see the discussion in chapter 3 ). The aim

\footnotetext{
${ }^{1}$ 54B Hristo Smirnenski Blvd, Sofia 1164, Bulgaria

${ }^{2}$ Department of Ecology and Environmental Protection, Sofia University „St. Kliment Ohridsky”, Faculty of Biology, 8 Dragan Tsankov Blvd., Sofia 1164, Bulgaria
} 
of the present study was to find out the syntaxonomical position of the dry grasslands, their relation to similar syntaxa described from SW Bulgaria and SE Serbia and, at the end, to give some reasonable explanation for their species composition and origin.

\section{METHODS AND MATERIALS}

The principles and methods of the ZürichMontpellier School (Braun-Blanquet 1951, Mueller-Dombois \& Ellenberg 1974, Westhoff \& van der Maarel 1980) were applied. We chose the plot size of $10 \times 10 \mathrm{sq}$. $\mathrm{m}$ as most adequate to make a more or less typical description of dry grasslands (Westhoff \& van der Maarel 1980). As a result of the sampling 38 relevés were made, which makes up to approximately $80 \%$ of the Bosnek karst region's territory covered with dry grasslands. At each sampling plot a complete list of the present species (vascular plants) was recorded, together with their cover-abundance value according to the 7-degree Braun-Blanquet scale - the one transformed by Barkman et al. (1964). For facilitating the statistical computer programs, the same scale is used, but transformed into ordinal numbers (Westhoff \& van der Maarel 1980).

For digitalizing and storing of the data we used the computer software TurboVeg (Hennekens \& Schamineé 2001). The sorting of the relevés was made in JUICE software (Tichý 2002). For the purpose of the numerical classification the TWINSPAN method is applied (TWo-way INdicator SPecies ANalysis) (Hill 1979) integrated in JUICE software. The results of the TWINSPAN analysis were compared with the cluster analysis made with the computer program SYN-TAX (Podani 2002), which was kindly provided by Dr. Marius Dimitrov (University of Forestry).

The diagnostic species of the published syntaxa were identified according to Horvat et al. (1974) and other referenced literature (see Chapter 3 - Syntaxonomical position). The syntaxa names and the names of their authors are given according to ICPN (Weber et al. 2000). The names of

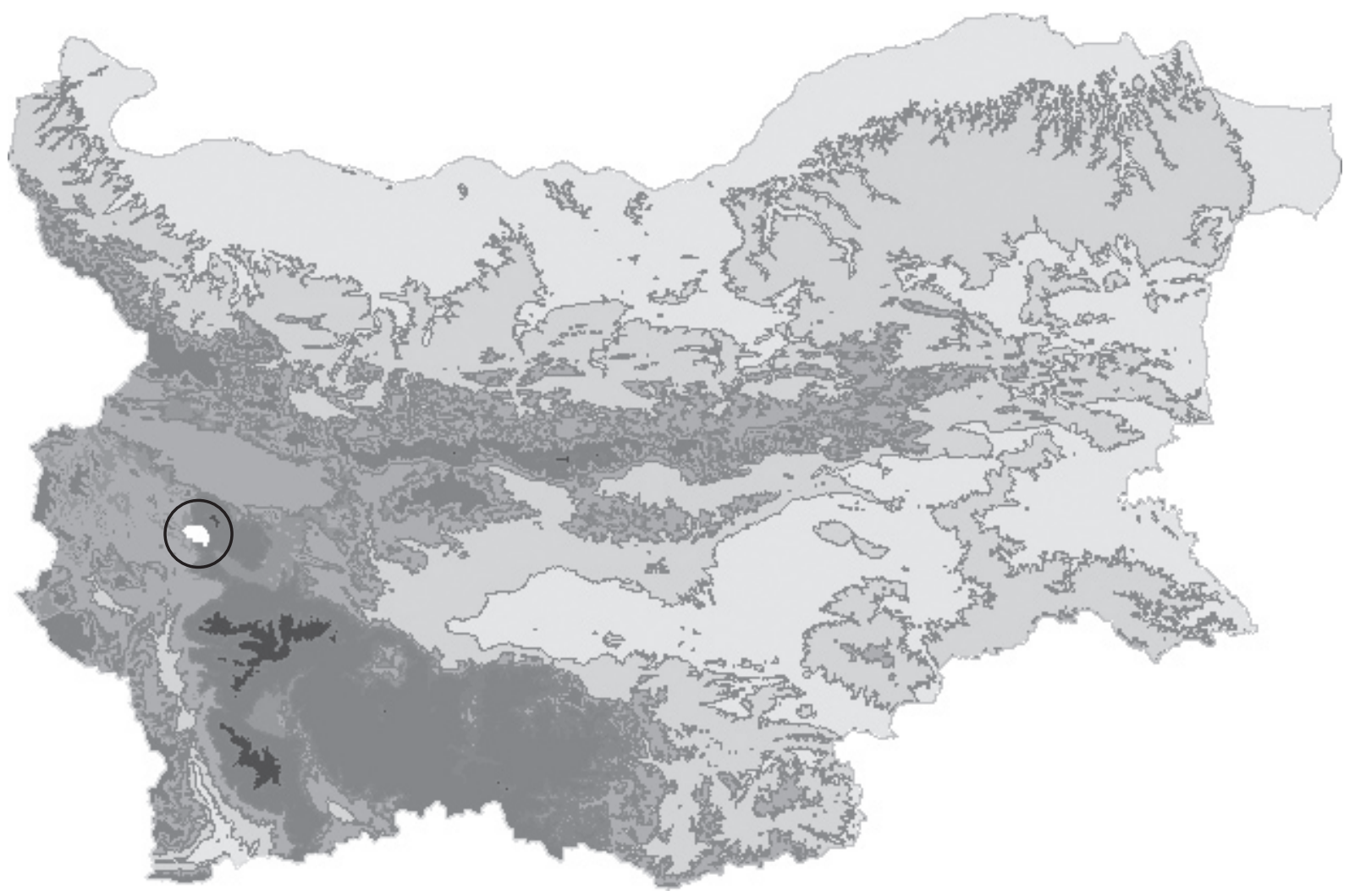

Figure 1: Location of the studied area on the map of Bulgaria.

Slika 1: Lokacija obravnevanega območja na zemljevidu Bolgarije. 
the plant taxa are given according to Delipavlov \& Cheshmedzhiev (2003). The floristic elements of the taxa are given according to Asyov et al. (2005), except for the subspecies (those for which there is no data available in Asyov et al. 2005), which are given according to Meusel et al. (1965). The life form of the species is given according to Raunkiaer (1934).

The object of the present study - dry grasslands - covers approximately $20 \%$ of the Bosnek karst region. The region lies within the southwestern foothills of Mt Vitosha, SW Bulgaria, and includes a branchy flattish mountainous area (approximately $23 \mathrm{sq} . \mathrm{km}$ ). The altitude varies between 830 and 1500 metres a. s. l. (see Figure 1). The bedrock consists of limestone and dolomite (Zagorchev et al. 1994). The karst rocks cover approximately $80 \%$ of the entire territory. The type of climate is temperately continental (Velev 2002), i.e. winters are cold and humid, and summers hot and dry, but the limestone bedrock and the shallow soils mitigate the local weather conditions in the winter and intensify them in the summer.

From a geobotanical point of view, the territory of the Bosnek karst region belongs to the Vitosha floristic region - part of the Illyric (Balkanic) province of the European deciduous forest region (Bondev 2002). Its borders lie within the belts of xerophilous oak and hornbeam forests and that of mesophilous beech forests.

\section{RESULTS \& DISCUSSION}

The analysis of the sampled phytosociological material manifests the existence of one single association which covers the entire territory of the Bosnek karst region. 38 relevés have been made, from which 3 were dropped out as a result of the cluster analysis made in SYN-TAX (Figure 2).

Figure 2: The result of the cluster analys of the relevés from Bosnek karstic region made in the computer program SYN-TAX (Podani 2002): A + B - Bromo moesiacae-Stipetum epilosae ass. nov.; A - var. typicum; B - var. siderites montana.

Slika 2: Rezultat klastrske analize popisov s kraškega območja Bosnek s programom SYN-TAX (Podani 2002): A + B - Bromo moesiacae-Stipetum epilosae ass. nova; A - var. typicum; B - var. sideritis montana.

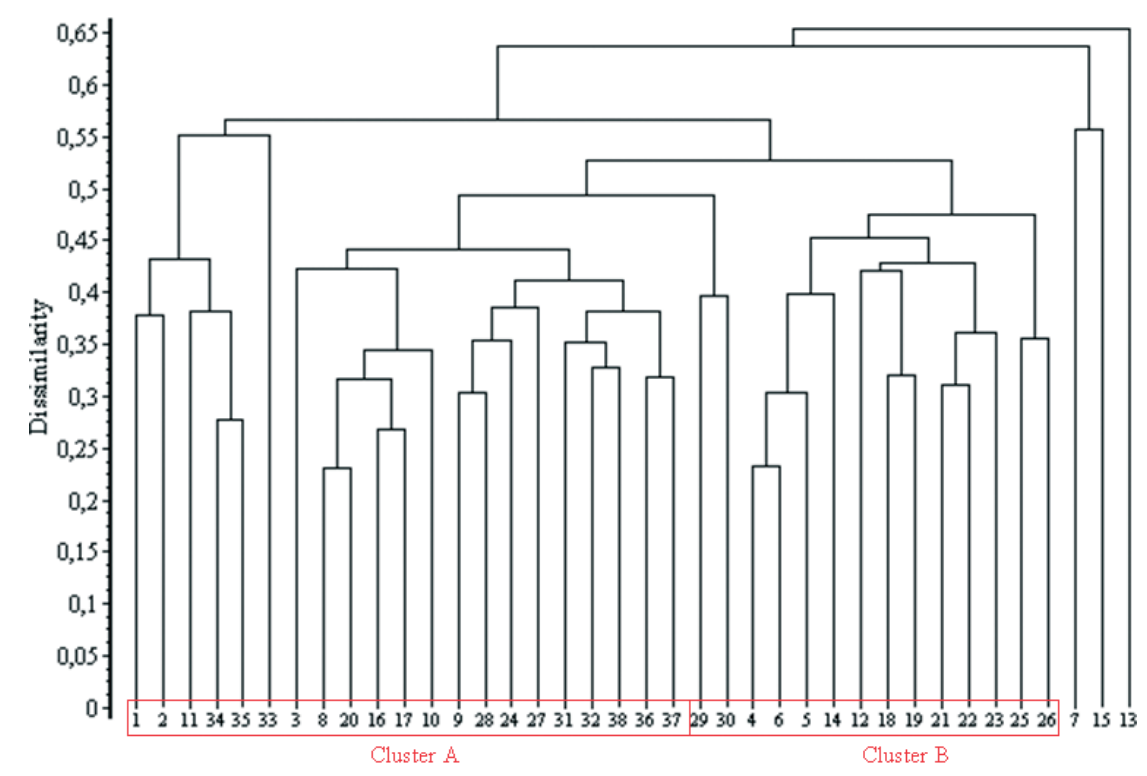

\section{CharaGteristics of the STUdied PHYTOCOENOSES}

In Bosnek karst region the studied vegetation is to be found on open, rocky places with poor soils (Figure 3). The structure of the phytocoenoses varies from an open to an almost closed one, as the total vegetation cover varies from $20 \%$ to $95 \%$ per plot. The mean cover is $75 \%$. The studied vegetation grows most frequently on slopes with southern exposition. The slope varies between $0^{\circ}$ and $65^{\circ}$, mean $-17^{\circ}$. The soils are mostly rendzinas - shallow, more or less eroded (Ninov 2002). The base rock is to be seen at the surface in many places as large fragments in different sizes or as gravel. In some sites the bare rock covers more than $60 \%$ of the sample plot (see Table 1). 


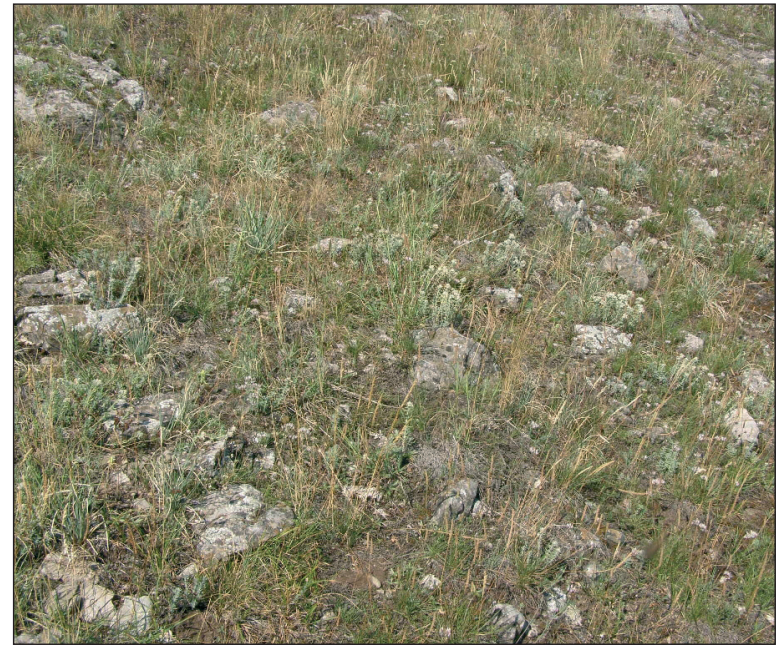

Figure 3: The studied vegetation is to be found on open, rocky places with poor soils. The bedrock is dolomite and carbonate.

Slika 3: Proučevano vegetacijo najdemo na odprtih, kamnitih rastiščih na slabo razvitih tleh. Matična podlaga je dolomit in apnenec.

The studied phytocoenoses are characterized by the little presence of trees and shrubs. There are only solitary shrubs and low trees such as $\mathcal{F} u$ niperus communis, Rosa myriacantha, Rosa agrestis, Rosa dumalis, Rosa canina, Corylus avellana, etc. They are bounded by remains of open xerothermic forests frequently dominated by Quercus pu-

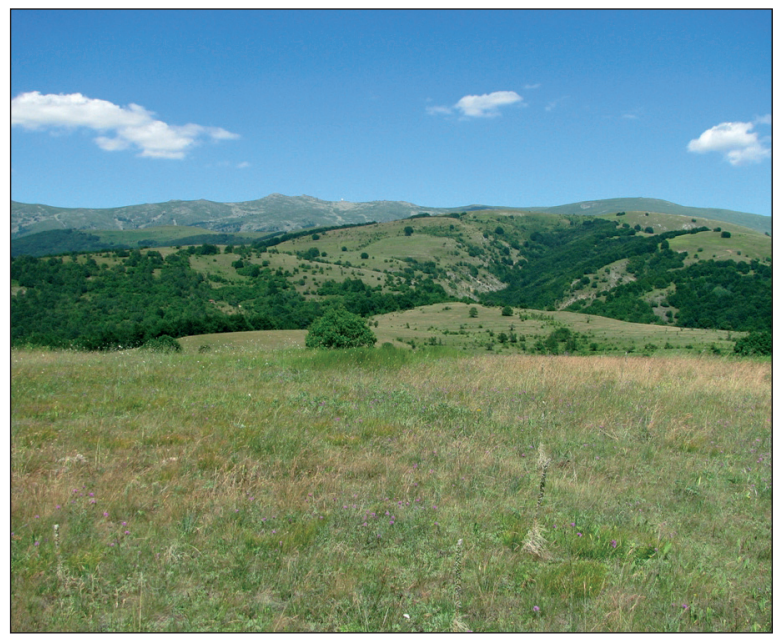

Figure 4: A general view to Bosnek karst region - the dry grasslands are bordered by mesothermic forests with Fagus sylvatica or remains of light xerothermic oak forests in the lower parts.

Slika 4: Pogled na območje Bosnek - suhi travniki so omejeni z mezotermnim bukovim gozdom ali ostanki kserotermnih hrastovih gozdov v spodnjem delu.

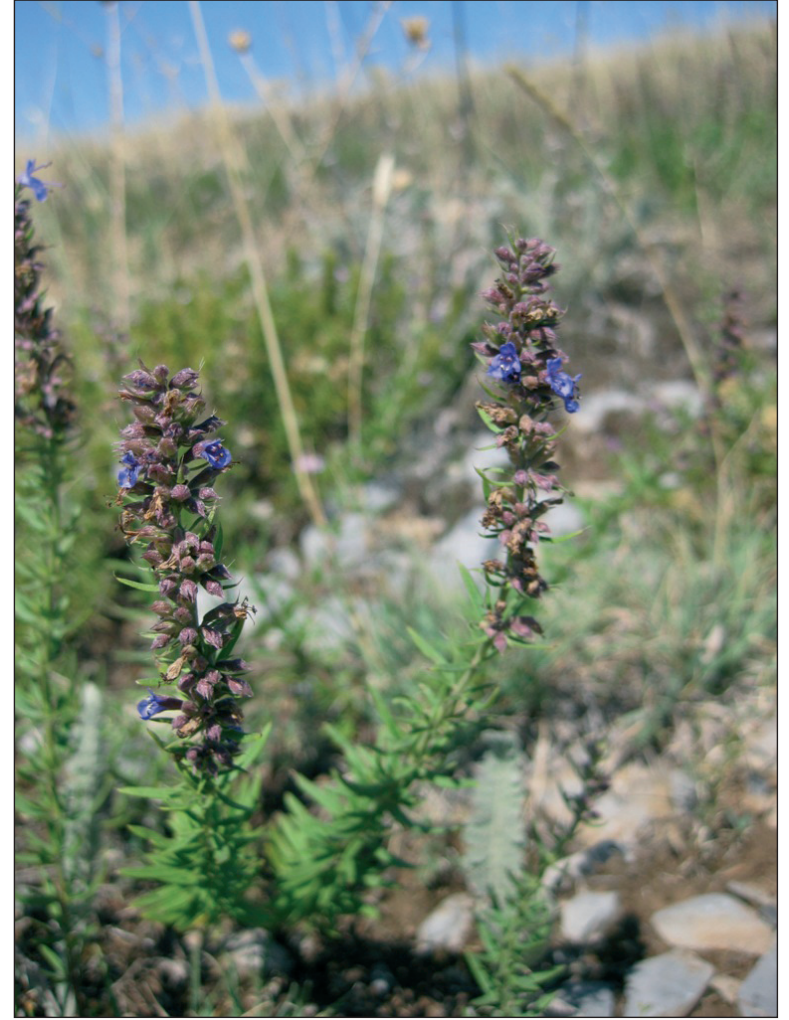

Figure 5: In the vegetation of Bosnek karst region there are a lot of aromatic chamaephytes such as Hyssopus officinalis spp. aristatus.

Slika 5: V vegetaciji kraške regije Bosnek je mnogo aromatičnih hamefitov kot Hyssopus officinalis spp. aristatus.

bescens and by other xerothermic species such as Fraxinus ornus, Carpinus orientalis, Cornus sanguin$e a$, etc. In the highest parts of the region they are surrounded by mesothermic forests with Fagus sylvatica (Figure 4).

The studied phytocoenoses are rich in species. The mean number of species is 46 but their number varies from 34 to 62 per relevé (see Table 1). The main dominants are grasses (Poaceae) and sedges (Cyperaceae) but frequent are also the aromatic chamaephytes from Lamiaceae (Figure 5). Typical for the phytocoenoses is the seasonality in flowering time, i.e. change in the color aspect of the community. In spring (March-April) Carex humilis (IV) and Potentilla cinerea (III) represent the yellow aspect and Hyacinthella leucophaea (II) and Muscari neglectum (II) represent the blue one. In the beginning of the summer (May-June) start to blossom most of the dominating species such as Stipa epilosa (V), Bromus moesiacus (V), Thymus striatus (V), Hypericum rumeliacum (V) (Figure 6). 


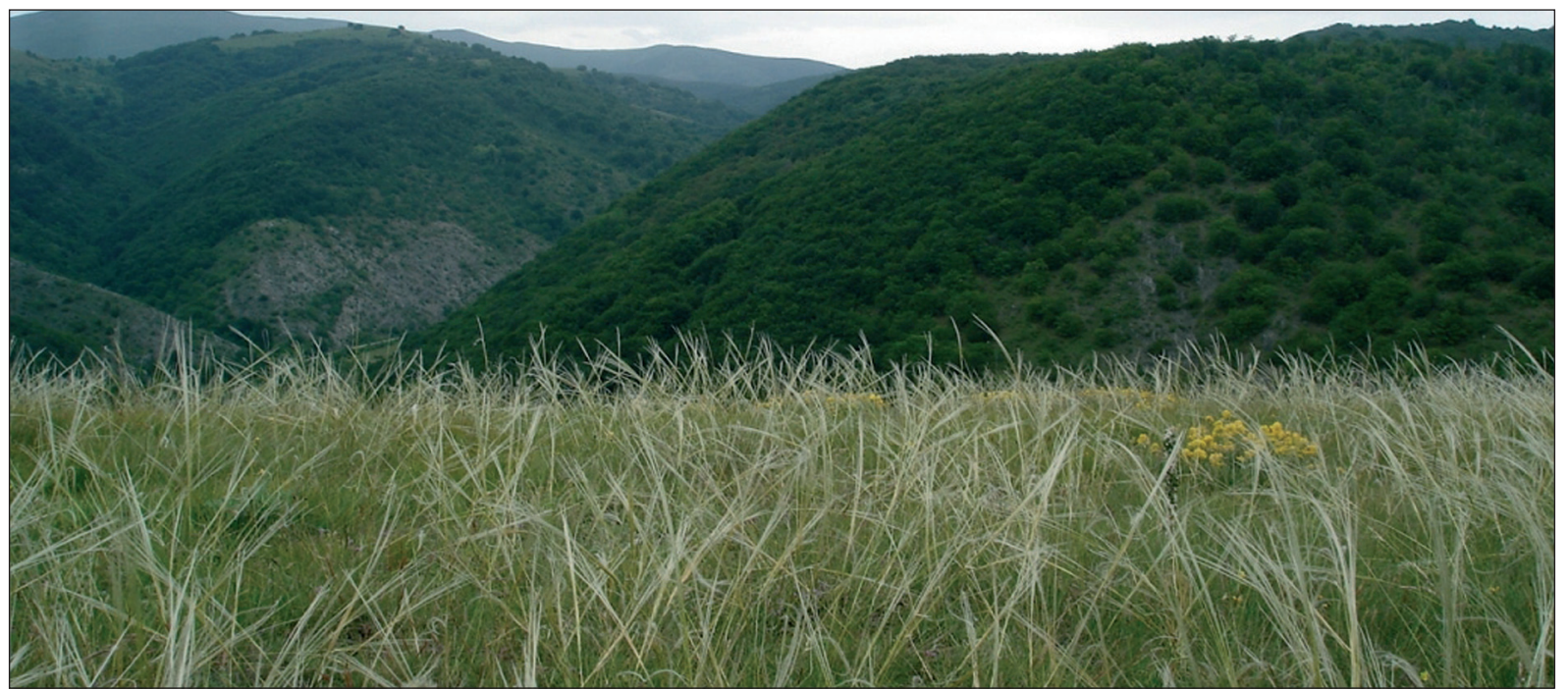

Figure 6: Stipa epilosa gives a characteristic spectrum of the studied phytocenoeses in spring time. Slika 6: Stipa epilosa daje značilen videz proučevani združbi v spomladanskem času.

\section{THE NEW SYNTAXON}

As a result of the numerical classification and the comparison with similar associations from Bulgaria and Serbia, we designated a new association Bromo moesiacae-Stipetum epilosae ass. nova, hoc. loco, holotypus nom. rel. 17, with the following diagnostic species Stipa epilosa (V), Bromus moesiacus (IV), Tragopogon balcanicus (III), Pimpinella tragium subsp. lithophila (V), Asphodeline taurica (IV), Thymus striatus (V), Hypericum rumeliacum (V) (Table 1). We consider this association to be a part of the relict petrophyte steppes, which centre of floristic differentiation and endemic plant species origin lies in the foot-hills of low karst mountains in West Bulgaria and East Serbia. Such steppic phytocoenoses are distinguished by the presence of vicariant species, especially among the grasses, by the degree of Mediterranean and Ponto-continental phytogeographical influences (which decrease to the north and to the west respectively) and by the number of endemics. Regarding the endemism, the newly established association is richer than those of Suva and Rtnaj Mts (see Jovanović-Dunjić 1955, 1956; Diklić 1962).

From a syntaxonomical point of view, we distinguish two variants regarding the extent of grazing effect and ruderalization. Phytocoenoses of variant typicum are dominated by hemicryptophytes and occupy sites where there is no grazing, or else the grazing is very limited. For example, the territory of the fenced Vitoshko-Stoudena game breed- ing station or on rocky steep slopes which are difficult to be accessed and have a low percent of total vegetation cover (Figure 7). The phytocoenoses of variant Sideritis montana include many therophytes and are distributed in more open and disturbed sites - usually close to dirt roads (Figure 8). In the phytocoenoses of that variant, ruderals and weeds such as Sideritis montana (V), Alyssum alyssoides (IV), Filago lutescens (IV), Xeranthemum annuum (II) are widely spread. Dorycnium herbaceum and Melica ciliata are differential species for variant Sideritis montana and variant typicum respectively.

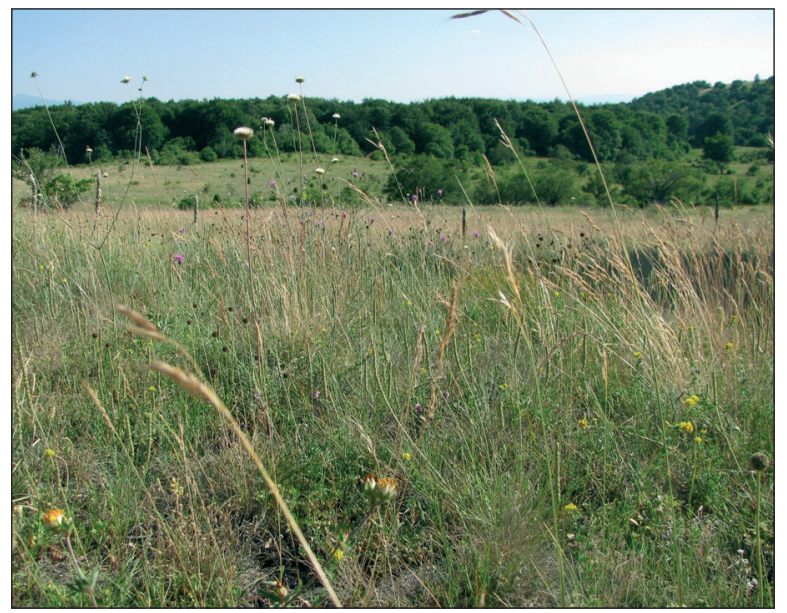

Figure 7: For variant typicum are characteristic species such as Globularia aphyllanthes, Scabiosa triniifolia, Jurinea consanguinea.

Slika 7: Za tipično varianto so značilne vrste Globularia aphyllanthes, Scabiosa triniifolia, Jurinea consanguinea. 


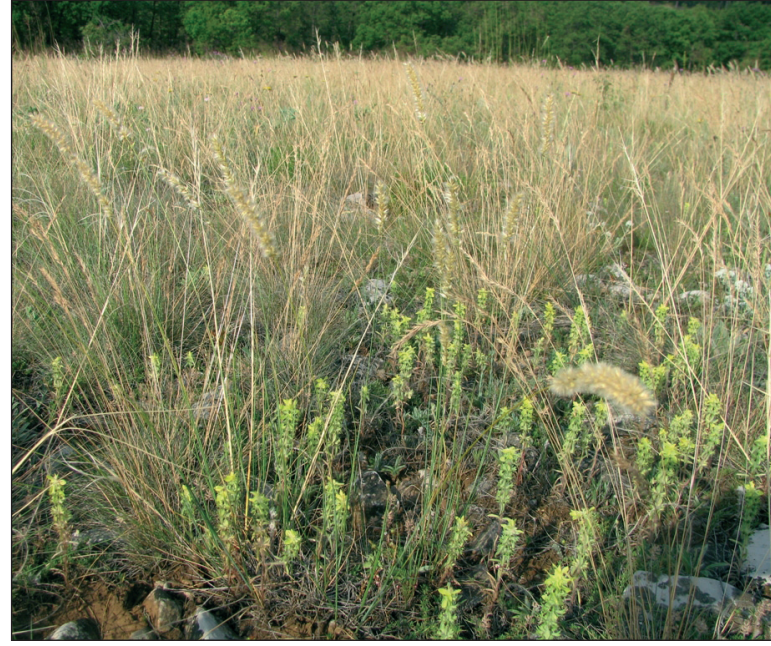

Figure 8: In variant Sideritis montana dominate therophytes such as Sideritis montana.

Slika 8: V sestojih variante sideritis montana prevladujejo terofiti kot je Sideritis montana.

\section{SYNTAXONOMICAL POSITION}

These communities are of continental-steppe origin and belong to the typical steppes characteristic for East and Central Europe - Festuco-Brometea Br.-Bl. \& Tüxen 1943 and Festucetalia valesiacae Br.-Bl. \& Tüxen 1943. We consider that it belongs to the alliance Saturejon montanae Horvat 1962, since many of the diagnostic species given for the alliance are presented with high constancy also in the newly established association (e.g. Satureja montana subsp. kitaibelii, Carex humilis, Potentilla cinerea, Festuca dalmatica, Rhodax canus, Artemisia alba, Teucrium montanum, Onobrychis alba, Asperula purpurea).

On the one hand, Saturejon montanae is described as a geographically and floristically autonomous syntaxon by Royer (1991) in his work on Festuco-Brometea in Europe. On the other hand, according to the synopsis that generalizes the vegetation in Serbia (Kojić et al. 1998), the steppe associations from Mts Suva and Rtanj are included in the more widely distributed Festucion valesiacae. Probably this is the reason why it was excluded from the list of the European syntaxa (Rodwell et al. 2002), as well as from SynBioSys Europe (http://www.synbiosys.alterra.nl/eu). We consider that the present study confirms the presence of such an alliance distributed within the range of West Bulgaria and partially in former Yugoslavia. Publications from other Bulgarian authors also confirm the presence of Saturejon montanae in SW, SE and N Bulgaria (Tzonev 2002, Apostolova-Stoyanova et al. 2005, Sopotlieva 2009, Pedaschenko et al. 2009).The diagnostic species of the alliance (Horvat et al. 1974) are adequate as characteristic ones and define its appearance, thus distinguishing it from Festucion valesiacae. In contrast to the latter alliance, in which phytocoenoses dominate perennial grasses on rich soils, phytocoenoses of Saturejon montanae are relatively open petrophyte steppes where grasses are co-dominants with tufted chamaephytes rich in aromatic oils, mainly from Lamiacaeae (Satureja spp., Thymus spp., Hyssopus spp., Teucrium spp.). These petrophyte steppes are to be found in the transitional zone between the continental and the mediterranean climate and their range coincides with that of the endemic for the Balkans species Satureja montana subsp. kitaibelii.

\section{COMPARISON WITH SIMILAR SYNTAXA From SW Bulgaria ANd E SERbia}

There are several publications dealing with steppe vegetation in the karst low-hilly mountains in SW Bulgaria and E Serbia. Velchev (1962) describes similar associations from the region of Dragoman - Belediye Han, but using the dominant method for classification. Three provisional associations were described from Mt Golo bardo (West Bulgaria) by Apostolova-Stoyanova et al. (2005) using the Blaun-Blanquet floristic approach. These associations belong to Satureion montanae Horvat 1962. Out of the three, Bromo moesiacae-Festucetum valesiacae nom. prov. should be considered as most similar to Bromo moesiacae-Stipetum epilosae ass. nova. Bromus moesiacus, Astragalus angustifolius, Bupleurum falcatum and Centaurea chrysolepis are given as diagnostic species; Festuca valesiaca, Artemisia campestris (more probably Artemisia alba), Satureja montana - as dominants. Despite the similarity in floristic composition and dominating species, most of the diagnostic species in the provisional syntaxon from Mt Golo bardo are not present in the new association. Actually, the syntaxon from Mt Golo bardo is closer to Astragalo-Silenetum supinae N. Rand. \& V. Milos. 2005 from Mt Rudina in Serbia. In the latter association a significant role is played by Astragalus angustifolius (Milosavljević \& Ranđelović 2006) - a species absent from Bromo moesiacae-Stipetum epilosae. Despite the presence of many common 
species (Allium cupani, Convolvulus cantabrica, Satureja montana, Thymus striatus), most of the species characteristic for Carici-Festucetum stojanovii N. Ranđ. \& V. Milos, 2005; Fritillario-Seslerietum rigidae N. Rand. \& V. Milos. 2004; Edraiantho-Anthylletum aureae N. Rand. \& V. Milos. 2005 do not have a diagnostic role or are not present at all in Bromo moesiacae-Stipetum epilosae. These are Sesleria rigida, Silene supina, Astragalus wilmottianus, Aster linosyris, Edraianthus serbicus, Achillea serbica, etc (see Milosavljević \& Ranđelović 2006).

Very close to Bromo moesiacae-Stipetum epilosae remain several associations described from East Serbia - mainly in Mt Suva and Rtanj (JovanovićDunjić 1955, 1956, Diklić 1962) and one from West Bulgaria - Lozenska planina (Pedashenko et al. 2009). There is a main core of species common to the Serbian syntaxa and the phytocoenoses from Mt Golo bardo, Mt Lozenska and the Dragoman karst region (West Bulgaria) (Velchev 1962, Apostolova-Stoyanova et al. 2005, Pedashenko et al. 2009). These are Satureja montana subsp. kitaibelii, Artemisia alba, Carex humilis, Potentilla cinerea, Asperula purpurea, Teucrium montanum, Melica ciliata, Teucrium chamaedrys, Euphorbia cyparissias. Future studies would possibly confirm the presence of that main core in other low karst mountains in West Bulgaria and East Serbia. Most of the listed species are specific for the climatic and edaphic conditions of that geographic region. Other species are widespread in many places in Bulgaria.

Since the phytosociological relevance of Bromo moesiacae-Stipetum epilosae and of the published syntaxa from East Serbia is quite obvious, we assume that it is expedient to look at the syntaxonomical similarities and differences between each of the above-mentioned associations and Bromo moesiacae-Stipetum epilosae (Table 2).

Myrsiniteto-Ischaemetum R. Jov. 1955 from Mt Suva has several essential similarities with Bromo moesiacae-Stipetum epilosae ass. nova, the main one being the high constancy of species such as Fumana procumbens (IV), Satureja montana (IV), Melica ciliata (V). On the other hand, most of the diagnostic species of that association are either not present or occur with low constancies in Bromo moesiacae-Stipetum epilosae. Among the latter are Botriochloa ischaemum and Euphorbia myrsinites (giving the name of the Serbian association), Allium moschatum, Chamaecytisus jankae, Adonis vernalis, Haplophyllum suaveolens. Many species frequent in Bromo moesiacae-Stipetum epi- losae are fully absent in phytocoenoses of Myrsiniteto-Ischaemetum.

Potentilleto-Caricetum humilis R. Jov. 1955 and Potentilleto-Caricetum humilis R. Jov. 1955 subass. artemisieosum camphoratae Diklić 1962 are even closely related to Bromo moesiacae-Stipetum epilosae ass. nov (Jovanović-Dunjić 1955, 1956, Diklić 1962). Common species (with high constancy for both) are presented by species from the previously mentioned main core as well as others such as Veronica austriaca, Galium album, etc. However, the differences are greater because both Serbian associations miss the gramineous species that dominate in Bromo moesiacae-Stipetum epilosae, in particular genus Stipa. Gramineous species from the Serbian associations with relatively high constancy are Festuca pančičiana (IV, IV) and Sesleria rigida (II, III); both absent from Bromo moesiacae-Stipetum epilosae. On top of that, on Mt Suva, which is a relatively high mountain (up to 1810 a.s.l.), there are some subalpine species such as Veratrum lobelianum, Arctostaphyllos uva-ursi, funiperus nana; that is to show that its grassland communities are quite mesophytic. Completely absent are many Mediterranean species, in particular some hemicryptophytes and therophytes such as Hypericum rumeliacum, Hippocrepis comosa, Coronilla scorpioides, Odontites glutinosa, etc. Absent are also many Balkan endemics and Pontic-eastsub-Mediterranean species (Bromus moesiacus, Tragopogon balcanicus, Asyneuma limonifolium, Asphodeline taurica, Hyacinthella leucophaea, Pimpinella tragium subsp. lithophila, Onosma visiani, Stipa epilosa) which are well presented (some with high constancy) in Bromo moesiacae-Stipetum epilosae (Figure 9).

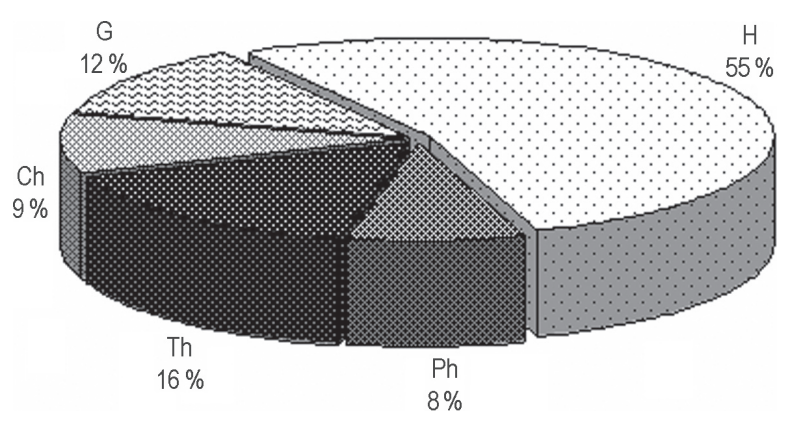

Figure 9: Life forms (Ch - chamaephytes, G - geophytes, $\mathrm{H}$ - hemicryptophytes, $\mathrm{Ph}$ - phanerophytes, $\mathrm{Th}$ - therophytes).

Slika 9: Življenske oblike (Ch - hamefiti, G - geofiti, H - hemikriptofiti, $\mathrm{Ph}$ - fanerofiti, $\mathrm{Th}$ - terofiti). 
The most similar Serbian association is Humileto-Stipetum pulcherrimae (synonym of HumiletoStipetum grafianae R. Jov. 1955) from Mt Suva, but the above-mentioned group of endemics and Pontic-east-sub-Mediterranean species are absent from that association too - a proof of the strong effect that the continental climate has on its floristic composition. Humileto-Stipetum pulcherrimae, having Stipa pulcherrima as a dominant (Stipa pulcherrima belong to the same aggregate as Stipa epilosa, i.e. Stipa pennata,), can be regarded as a vicariant of Bromo moesiacae-Stipetum epilosae.

Undoubtedly, the greatest similarity is with Hyperico rochelii-Stipetum epilosae from Mt Lozenska (Pedashenko et al. 2009). Beside the abovementioned main core of common species there many of others that have high constancies both in Hyperico rochelii-Stipetum epilosae and in Bromo moesiacae-Stipetum epilosae. Moreover, two of the diagnostic species for Bromo moesiacae-Stipetum epilosae are present with high constancy in Hyperico rochelii-Stipetum epilosae. However, the above-mentioned group of endemics and Pontoeast-sub-Mediterranean species is missing from Hyperico rochelii-Stipetum epilosae, and only one of its six diagnostic species is to be found in Bromo moesiacae-Stipetum epilosae.

From the stated facts we can infer that Bromo moesiacae-Stipetum epilosae although in some terms very similar to some Serbian and Bulgarian associations- in particular Stipetum pulcherrimae and Hyperico rochelii-Stipetum epilosae- should be considered as an independent one. The main reason for its autonomy is the specific complex of endemic and Ponto-Mediterranean species such as Bromus moesiacus (IV), Tragopogon balcanicus (III), Hypericum rumeliacum (V), Pimpinella tragium subsp. lithophila (V), Asphodeline taurica (IV), Scabiosa triniifolia (IV), furinea consaguinea (II), Thymus striatus (V).

\section{HyPOTHESES ABOUT THE ORIGIN OF THE STUDIED VEGETATION}

The analysis of the biological spectrum (Figure 9) gives an apportionment of life forms that is characteristic for grasslands with steppe origin (Steffanov 1943), while the apportionment of the geoelements shows a strong Mediterranean influence (Figure 10). The specificity of the studied phytocoenoses is underlined by the high percent of Balkan endemic species such as Tragopogon bal-

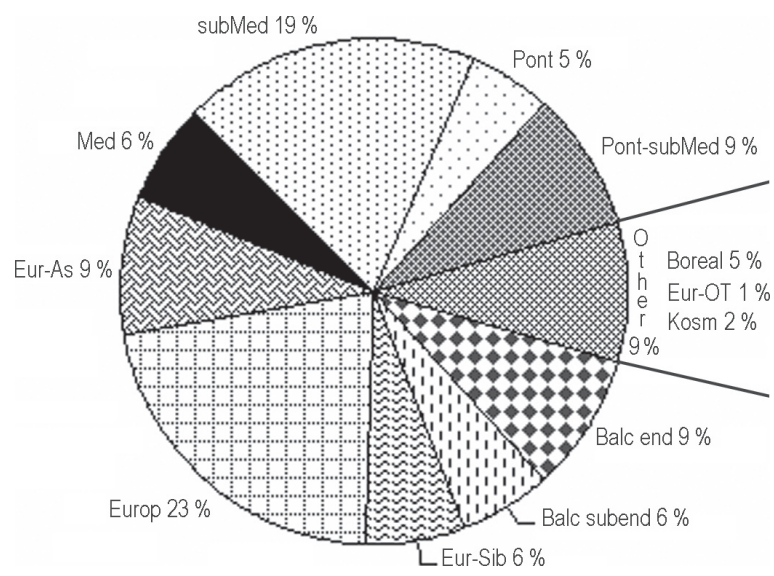

Figure 10: Geoelements $(\underline{\text { Note}}:$ Balc endemic $=$ Balc + Bul; Balc subendemic $=$ Alp-Carp-Bal + Ap-Bal + Bal-Anat + Balc-Dac; Boreal $=$ Boreal + subBoreal, Europ $=$ CSEur + Eur + Euro-Med + Eur-subMed; Eur-Sib = Eur-Sib + SSib + subMed-Sib; Eur-As = Eur-As + Med-CAs + subMed-As; Eur-OT $=$ Eur-OT + Med-OT + Eur-Med-OT; Kosm = Kosm; Med = Med + OMed; subMed = subMed; Pont $=$ Pont + Pont-Bal + Pont-Sib + Pont-CAs + Pont-Sib + SPont; PontsubMed $=$ Pont-Med + Pont-subMed).

Slika 10: Geoelementi (Okrajšava: Balc endemic $=$ Balc + Bul; Balc subendemic $=$ Alp-Carp-Bal + Ap-Bal + Bal-Anat + Balc-Dac; Boreal $=$ Boreal + subBoreal, Europ $=$ CSEur + Eur + Euro-Med + Eur-subMed; Eur-Sib = Eur-Sib + SSib + subMed-Sib; Eur-As = Eur-As + Med-CAs + subMed-As; Eur-OT $=$ Eur-OT + Med-OT + Eur-Med-OT; Kosm = Kosm; Med = Med + OMed; subMed = subMed; Pont $=$ Pont + Pont-Bal + Pont-Sib + Pont-CAs + Pont-Sib + SPont; PontsubMed $=$ Pont-Med + Pont-subMed).

canicus (III), Achillea clypeolata (II), Minuartia bosniaca (I), Genista subcapitata (I), Anthyllis aurea (I); and two regional Bulgarian endemics - Bromus moesiacus (IV), Verbascum urumovii (I). Most of these endemics, as well as others which are not present in the Bosnek karst region (e.g. Edrajanthus serbicum, Astragalus wilmottianus, furinea tzarferdinandii, Tulipa urumovii, Erysimum comatum, Malcomia serbica, Verbascum eriophorum), are distributed also in other low calcareous mountains in W Bulgaria and E Serbia, respectively Golo Bardo, Chepan, Ruy, Konyavska, Lyubash in Bulgaria; and Suva and Rtanj in Serbia. According to Steffanov (1943), this group of endemic species originates from the Serbo-Illyrian endemic centre of species origin and serves as a proof for the relict origin of some grasslands in that region (W Bulgaria and E Serbia).

The floristic composition of grasslands on karst terrains in W Bulgaria includes also numer- 
ous thermophytes from the northern continental centre (Steffanov 1943) with mostly Pontho-steppic origin: Agropyron cristatum, Paeonia tenuifolia, Amygdalus nana, Astragalus pubiflorus, Inula ensifolia, Anemone sylvestris. Stoyanoff (1941) uses this complex of species to prove the primary grassland character of plant communities. The author considers both the continental climate and the edaphic peculiarities of limestone bedrock as a reason for the absence of forests in some parts of the karst mountains. In addition to that, Yordanoff (1936) considers only edaphic conditions (the eroded, poor soils are too dry to support forests) as the main factor for the existence of primary grassland vegetation in some parts of these mountains because the climate in the region, even though having continental amplitudes, is characterized by sufficient annual rainfalls. The author gives as a proof of his thesis a research on Mt Vitosha (Georgieff 1929) that lists plant species from the vicinity of Krapetz village, i.e. the Bosnek karst region.

We assume that part of the calcareous grasslands in W Bulgaria has a relict origin and dates back to the time of maximum distribution of steppes on Bulgarian territory. That time coincides with the Boreal phase of the Holocene (Bozhilova 1986, Palamarev 2002 etc.). During the Holocene the preservation of grasslands in the mountains of $\mathrm{W}$ Bulgaria was aided by the specific edaphic and thermic conditions of the karst, which hindered the forest invasion (Yordanoff 1936). This does not exclude the presence of forests there, which grow in the present time on the northern and eastern slopes of the low karst mountains - Chepan, Mt Koyavska, Golo Bardo. The development of forests on Mt Vitosha has been established from some palynological investigations. For example, Filipovich (1988) found a great participation of Quercus, Coryllus, Betula spp., which extended up to $1900 \mathrm{~m}$. a. s. l. on Mt Vitosha during the Atlantic period of the Holocene (6000 BP). Some authors consider some of these tree and shrub species as indicators for the presence of more open (mixture forest-grassland) landscapes (Poshlod \& Baumann 2010). The secondary expansion of grasslands on calcareous terrains has happened after the increase of human activities. This assumption has been made for the calcareous grasslands in Central Europe (see Poschlod \& WallisDeVries 2002). The open structure of the calcareous grasslands allowed the penetration of many thermophilous
Mediterranean species during the favourable climate changes of the Holocene. To this group of Mediterranean species belong some dominant grasses such as Chrysopogon gryllus and Botriochloa ischaemum (see Jordanoff 1936). At the same time, the long-term preservation of intrazonal grassland vegetation within the zonal thermophilous forests in the isolated low karst mountains in West Bulgaria has led to the origin of endemic forms. These species together with the newly penetrated Mediterranean species and the relict steppe taxa make up the diverse and rich floristic complex that defines the specificity of grassland vegetation in that part of the country.

\section{CONCLUSIONS}

a) We established a new association designated as Bromo moesiacae-Stipetum epilosae ass. nova, hoc. loco, with diagnostic species Stipa epilosa (V), Bromus moesiacus (IV), Tragopogon balcanicus (III), Asphodeline taurica (IV), Pimpinella tragium subsp. lithophila (V), Thymus striatus (V), Hypericum rumeliacum (V), b) Its phytocoenoses are distinguishable from the other associations in SW Bulgaria and SE Serbia by the presence of vicariant species, by the extent of Mediterranean and Pontocontinental phytogeographical influence and by the number of endemic taxa, c) We consider that this association is part of the relict petrophyte steppes with endemic centre in the low karst mountains of West Bulgaria and East Serbia, d) Bromo moesiacae-Stipetum epilosae ass. nova, hoc. loco confirms the presence of the alliance Saturejon montanae. A more precise profile of Saturejon montanae and its ecological and geographical characteristics could be gained through a future revision and gathering of additional information about the steppe plant communities in West Bulgaria and East Serbia.

\section{ACKNOWLEDGEMENTS}

The authors would like to express their thanks to BBF - Bulgarian Biodiversity Foundation and Vitosha Nature Park Directorate for the financial support for the field investigations. We would also like to thank "Sylvica" Foundation (BSFP) for giving permission to use the programme SYNTAX, and Assoc. Prof. Dr. Marius Dimitrov for the technical support. 


\section{REFERENGES}

Apostolova-Stoyanova, N., Pavlov, D. \& Dimitrov, M. 2005: A study of the syntaxonomical diversity of the vegetation in the northwest parts Mt of Golo bardo. In: Brezin, V. et al. (eds.): Scientific works from the National scientific conference "Young scientists" 2005", Sofia: pp. 26-31 (in Bulgarian)

Asyov, B., Petrova, A., Dimitrov, D. \& Vasilev, R. 2006: Conspectus of the vascular plants in Bulgaria. Bulgarian Biodiversity Foundation, Sofia: 453 pp. (in Bulgarian)

Barkman, J. J., Doing, H. \& Segal, S. 1964: Kritische Bemerkungen und Vorschlage zur quantitativen Vegetationsanalyse. Acta Botanica Neederlandica, 13: 394-419.

Bondev, I. 2002: Geobotanical regionalization. In: Kopralev et al. (eds.): Geography of Bulgaria. ForKom, Sofia: pp 336-351. (in Bulgarian)

Bozhilova, E. 1986: Palaeoecological conditions and changes of the vegetation in Southern and Southwestern Bulgaria during the last 15000 years. Great PhD Thesis. Sofia University, Faculty of Biology, Sofia (in Bulgarian, unpubl): 318 pp.

Braun-Blanquet, J. 1951: Pflanzensoziologie, Grundzüge der Vegetationskunde. 2nd edition. Springer Verlag, Wien: 631 pp.

Delipavlov, D. \& Cheshmedzhiev, I. (eds.). 2003: Key to the Plants of Bulgaria. Acad. Press, Agricultural University, Plovdiv: 591 pp. (in Bulgarian)

Diklić, N. 1962: Prilog poznavanju šumskih i livadskih fitocenoza Ozrena, Device i Leskovika kod Soko Banje. Glasnik Prirodnjačkog muzeja u Beogradu, B18: 49-83. (in Serbian)

Georgieff, T. 1929: Phytogeographical outline of Mt Vitosha. Ann. Sofia University, Faculty of Agronomy, 6: 179-209. (in Bulgarian)

Hennekens, S.M. \& Schamineé, J.H.J. 2001: Turboveg, a comprehensive database management system for vegetation data. Journal of Vegetation Science, 12: 589-591.

Hill, M.O. 1979: TWINSPAN. A FORTRAN program for arranging multivariate data in an ordered two-way table by classification of individuals and attributes. Cornell University, Ithaca, New York.

Horvat, I., Glavać, V. \& Ellenberg, H. 1974: Vegetation Südosteuropas. Geobotanica selecta, 4. VEB Gustav Fischer Verlag, Jena: 768 pp.
Jovanović-Dunjić, R. 1955: Weiden- und wiesentypen der Suva planina. Zborn. Rad. Inst. za ekol. i biogeografiju, 6(2). SAN, Beograd: 545. (in Serbian)

Jovanović-Dunjić, R. 1956: Les types des prés et des paturages a la montagne de Rtanj. Zborn. Rad. Inst. za ekol. i biogeografiju, 6 (1). SAN, Beograd: 5-45. (in Serbian)

Kojić, M., Popović, R. \& Karažić, B. 1998: Sintaksonomski pregled vegetacije Srbije. Institut za biološka istraživanja "Siniša Stankovič", Beograd (in Serbian)

Meusel, H., Jager, E. \& Weinert, E. 1965: Vergleichende chorologie der Zentraleuropaischen Flora. Text. Veb Gustav Fischer Verlag, Jena: $583 \mathrm{pp}$.

Milosavljević, V. \& Ranđelović, N. 2006: Pašnjaci krečnjačkog dela Rudina planine. Ekološka Istina, 27.-30.05.2007, Hotel "Zdravljak", Sokobanja: 76-80.

Mueller-Dombois, D. \& Ellenberg, H. 1974: Aims and methods of vegetation ecology. Wiley, London: $547 \mathrm{pp}$.

Ninov, N. 2002: Soils. In: Kopralev, I. (ed.): Geography of Bulgaria. Physical geography. Socio-economic geography. ForKom, Sofia: pp. 277-315. (in Bulgarian)

Palamarev, I. 2002: Basic stages in the development of the vegetation and flora during the geological past of our country. In: Kopralev, I. (ed.): Geography of Bulgaria. Physical geography. ForKom, Sofia: pp. 317-321. (in Bulgarian)

Pedaschenko, H., Meshinev, T. \& Apostolova, I. 2009: Herbaceous vegetation on carbonate terrains in Mt Lozenska. Phytologia Balcanica, 15 (2), Sofia: 245-253.

Podani, J. 2002: SYN-TAX-pc. Computer Programs for Multivariate Data Analysis in Ecology and Systematics. Scientia Publishing, Budapest: 53 pp.

Raunkiaer, C. 1934: The life form of plants and statistical plant geography. Clarendon press, Oxford: $632 \mathrm{pp}$

Rodwell, J., Schamineé, J., Mucina, L., Pignatti, R., Dring, J. \& Moos, D. 2002: The Diversity of European Vegetation. An overview of phytosociological Alliances and their relationships to EUNIS habitats. Landbouw, natuurbeheer en visserij, Wageningen: $168 \mathrm{pp}$.

Royer, J. M. 1991: Synthèse eurosibérienne, phytosociologique \& phytogéographique de la classe des Festuco-Brometea. Dissertaciones 
Botanicae 178, Verlag J. Cramer, Berlin-Stuttgart: 296 pp.

Sopotlieva, D. 2009: The high-rank syntaxa of semi-natural grasslands in Straldzha-Aytos phytogeographic region. In: Ivanova, D. (ed.): Proceedings of IV Balkan Botanical Congress, 20-26 June 2006, Sofia: pp. 303-307.

Steffanov, B. 1943: Phytogeographishe elementen in Bulgarien. Bull. BAS, 39: 550 pp. (in Bulgarian)

Stoyanoff, N. 1925: On the xerothermic vegetation element in Bulgaria. Ann. Sofia University, Faculty of Agronomy, 3: 317-248. (in Bulgarian)

Stoyanoff, N. 1941: Versuch einer Phytozoenologishen charakteristik Bulgariens. Ann. Sofia University, Faculty of Physics and Mathematics, Sofia, 34(3): 93-184. (in Bulgarian)

Tichý, L. 2002: JUICE, software for vegetation classification. Journal of Vegetation Science, 13: 451-453.

Tzonev, R. 2002: Flora and vegetation in the Middle Danubian Plain between the valleys of Vit and Studena River. PhD Thesis. Sofia University, Faculty of Biology, Sofia (in Bulgarian, unpubl.).
Velchev, V. 1962: The herbaceous cover of the carbonate terrains in the region of Dragoman Beledie Han, Sofia region. BAS, Sofia: 132 pp. (in Bulgarian).

Velev, S. 2002: Climatic regionalisation. In: Kopralev, I. (ed.): Geography of Bulgaria. Physical geography. ForKom, Sofia: pp. 155-156 (in Bulgarian).

Weber, H. E., Moravec, J. \& Theurillat, J.-P. 2000: International Code of Phytosociological Nomenclature. 3rd edition. Journal of Vegetation Science, 11: 739-768.

Westhoff, V. \& van der Maarel, E. 1980: The Braun-Blanquet Approach. In: Whittaker, R. H. (ed.): Classification of Plant Communities. Junk, The Hague: pp. 289-399.

Yordanoff, D. 1936: On the distribution of the steppe vegetation in Bulgaria. Bull. BAS, 32(5): 1-105. (in Bulgarian)

Zagorchev, I., Marinova, R., Chunev, D. and Chumachenko, P. 1994: Geologic map of Bulgaria. Map sheet of Pernik. Clarifying report. Committee of geology and mineral resources, Sofia: 92 pp. (In Bulgarian)

Received 25.3.2010

Revision received 30.6.2010

Accepted 4.7.2010 
Table 1 (Tabela 1): Ass. Bromo moesiacae-Stipetum epilosae ass. nova

\begin{tabular}{|c|c|c|c|c|c|c|c|c|c|c|c|c|c|c|c|c|}
\hline \multirow{6}{*}{ 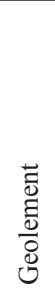 } & & \multirow{3}{*}{$\begin{array}{l}\text { Cluster, № } \\
\text { Number of relevés: } \\
\text { Relevé № } \\
\end{array}$} & \multicolumn{14}{|c|}{$\mathbf{A}$} \\
\hline & & & \multicolumn{14}{|c|}{21} \\
\hline & \multirow{6}{*}{ 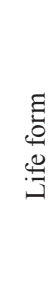 } & & 3 & 11 & 2 & 10 & 1 & 20 & 16 & 17 & 24 & 37 & 27 & 38 & 36 & 31 \\
\hline & & altitude (m x10) & 105 & 97,3 & 105 & 119 & 102 & 111 & 119 & 120 & 121 & 140 & 145 & 133 & 139 & 130 \\
\hline & & slope $\left(^{\circ}\right)$ & 5 & 60 & 26 & 7 & 27 & 17 & 0 & 7 & 1 & 20 & 1 & 3 & 20 & 8 \\
\hline & & exposition & 岳 & 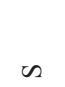 & 恶 & $\sum_{1}^{z}$ & 㭊 & $\begin{array}{l}3 \\
3 \\
3 \\
3\end{array}$ & ' & $\begin{array}{l}3 \\
\text { in } \\
\text { in }\end{array}$ & 山 & 峉 & Z & $\begin{array}{l}\overrightarrow{3} \\
\infty \\
i \\
n\end{array}$ & $\begin{array}{l}\text { 亗 } \\
\text { 1' } \\
\text { ஸे }\end{array}$ & $\begin{array}{l}3 \\
n \\
1 \\
13 \\
3\end{array}$ \\
\hline & & total vegetation cover, $\%$ & 90 & 35 & 70 & 70 & 70 & 70 & 95 & 85 & 80 & 40 & 95 & 80 & 40 & 60 \\
\hline & & Bare stones $(\%)$ & 0 & 60 & 5 & 20 & 15 & 20 & 0 & 5 & 0 & 50 & 2 & 0 & 60 & 40 \\
\hline
\end{tabular}

$\begin{array}{ll}\text { SSEur } & \text { G Stipa epilosa } \\ \text { subMed } & \text { Ch Thymus striatus } \\ \text { Bal } & \text { H Hypericum rumeliacum }\end{array}$

Pont-subMed H Pimpinella tragium ssp. lithophila

Bul G Bromus moesiacus

Pont-Med G Asphodeline taurica

Bal H Tragopogon balcanicus

\section{var. typicum}

Bal H Scabiosa triniifolia

Eur H Globularia aphyllanthes

Eur-Med Ch Carlina acanthifolia

Eur H Dorycnium herbaceum

subMed-Sib H Jurinea consaguinea

Eur-Med H Hieracium pilosella

SSib G Brachypodium pinnatum

var. Sideritis montana

subMed Th Sideritis montana

Eur-Med H Sedum acre

Eur-subMed G Melica ciliata

Boreal Th Filago lutescens

Eur-Med Th Alyssum alyssoides

subMed Th Coronilla scorpioides

subMed Th Xeranthemum annuum

Eur-OT G Allium rotundum

Eur-Med Th Euphorbia exigua

\section{All. Saturejon montanae Horvat 1962}

Pont G Festuca dalmatica

Bal Ch Satureja montana ssp. kitaibelii

Pont Ch Rhodax canus

subMed H Asperula purpurea

Eur-As G Carex humilis

Eur-Med H Anthyllis vulneraria ssp. pulchella

Eur G Potentilla cinerea

Pont-Med Ch Fumana procumbens

subMed Ch Teucrium montanum

subMed Ch Artemisia alba

Bal H Achillea clypeolata

Bal H Onobrychis alba ssp. calcarea

subMed $\quad \mathrm{Ph}$ Rosa myriacantha

Eur-Sib G Vincetoxicum hirundinaria

\begin{tabular}{|cccccccccccccc}
\hline 4 & $2 \mathrm{a}$ & $\mathbf{2 b}$ & $\mathbf{2 b}$ & $\mathbf{2 b}$ & $\mathbf{3}$ & $\mathbf{2 b}$ & $\mathbf{2 a}$ & $\mathbf{1}$ & $\mathbf{1}$ &. & $\mathbf{2 a}$ &. & $\mathbf{2 a}$ \\
1 &. & $\mathbf{1}$ & + & $\mathbf{2 a}$ & + & $\mathbf{1}$ & $\mathbf{1}$ & $\mathbf{1}$ & + & $\mathbf{1}$ & $\mathbf{1}$ & $\mathbf{1}$ &. \\
$2 \mathrm{~m}$ & + &. & + & + & + & $\mathbf{2}$ & + & $\mathbf{1}$ & + &. &. & + & + \\
. & + & 1 & $\mathbf{1}$ & + & + & $\mathbf{1}$ & + & + & + & $\mathbf{1}$ &. & + & + \\
$2 \mathrm{a}$ & $2 \mathrm{a}$ &. & $2 \mathrm{a}$ &. &. & $\mathbf{2 b}$ & $\mathbf{2 a}$ & $\mathbf{3}$ & $\mathbf{1}$ & $\mathbf{2 b}$ & $\mathbf{2 a}$ & $\mathbf{2 a}$ & $\mathbf{1}$ \\
1 & + & + & + &. & + & $\mathbf{1}$ & $\mathbf{1}$ & + &. &. &. &. & + \\
. &. &. &. & + & + &. & + &. & + &. &. &. &. \\
\hline
\end{tabular}

\begin{tabular}{cccccccccccccc}
+ & + & $\mathbf{1}$ & $\mathbf{1}$ & + & + & + & + & + & + & $\mathbf{1}$ & + & + & + \\
+ & $\mathbf{1}$ & + & + & $\mathbf{1}$ &. & $\mathbf{1}$ & + & + & + & $\mathbf{1}$ & + & + & $\mathbf{1}$ \\
+ &. &. &. & + & + & $\mathbf{1}$ & + &. & + & + & + & 1 & + \\
. & $\mathbf{1}$ & $\mathbf{2 b}$ &. & $\mathbf{2 a}$ &. &. &. & $\mathbf{2 a}$ & $\mathbf{1}$ & $\mathbf{1}$ & $\mathbf{1}$ & $\mathbf{1}$ & $\mathbf{1}$ \\
+ & $\mathbf{r}$ &. &. & + & + & + & + &. & + &. & + &. &. \\
. & + & $\mathbf{1}$ &. & $\mathbf{1}$ &. & + & + & + & + & $\mathbf{1}$ & + &. &. \\
. & + & $\mathbf{1}$ &. & $\mathbf{1}$ &. &. &. &. & + & $\mathbf{1}$ & + & + & + \\
\hline
\end{tabular}




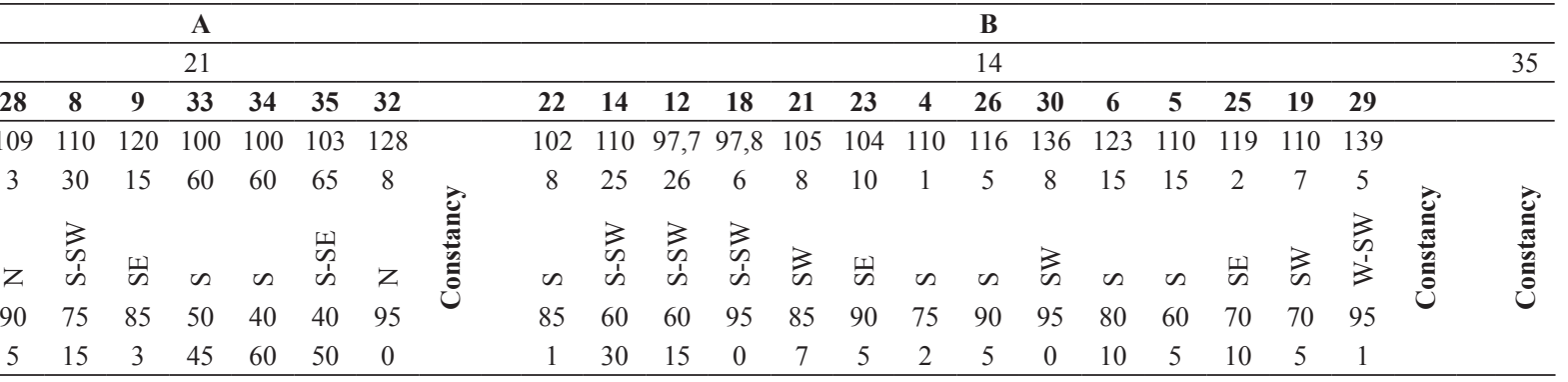

\begin{tabular}{ccccccccccccccccccccccccc}
\hline $\mathbf{2 a}$ & $\mathbf{2 a}$ & $\mathbf{2 b}$ & + & $\mathbf{1}$ & $\mathbf{1}$ & & $\mathbf{V}$ & $\mathbf{3}$ & $\mathbf{2 a}$ & $\mathbf{2 a}$ & $\mathbf{2 b}$ & $\mathbf{2 a}$ & $\mathbf{2 b}$ & $\mathbf{1}$ & $\mathbf{2 a}$ &. & $\mathbf{1}$ & $\mathbf{1}$ & $\mathbf{2 a}$ & $\mathbf{2 a}$ &. & $\mathbf{V}$ & $\mathbf{V}$ \\
$\mathbf{2 a}$ & $\mathbf{2 a}$ & $\mathbf{1}$ & $\mathbf{1}$ & + & + & $\mathbf{1}$ & $\mathbf{V}$ & $\mathbf{1}$ & $\mathbf{1}$ & $\mathbf{1}$ & $\mathbf{1}$ & + & + & $\mathbf{1}$ & $\mathbf{2 a}$ & $\mathbf{1}$ & $\mathbf{1}$ & $\mathbf{1}$ & $\mathbf{1}$ & $\mathbf{1}$ & + & $\mathbf{V}$ & $\mathbf{V}$ \\
$\mathbf{2 m}$ & + & + & + & + & + & $\mathbf{2 m}$ & $\mathbf{V}$ & + & + & + & $\mathbf{1}$ & + & $\mathbf{2 m}$ & + & $\mathbf{1}$ & $\mathbf{2 m}$ & $\mathbf{1}$ & + & + & $\mathbf{1}$ & $\mathbf{2 m}$ & $\mathbf{V}$ & $\mathbf{V}$ \\
$\mathbf{1}$ & + & + & + & + & + & $\mathbf{1}$ & $\mathbf{V}$ & &. & + & + &. & + & $\mathbf{1}$ & + & $\mathbf{1}$ & + & + & + & + & + & $\mathbf{1}$ & $\mathbf{V}$ & $\mathbf{V}$ \\
. &. & $\mathbf{2 a}$ &. & $\mathbf{2 a}$ & $\mathbf{1}$ & $\mathbf{2 b}$ & $\mathbf{I V}$ &. & $\mathbf{2 a}$ & $\mathbf{2 a}$ & $\mathbf{2 b}$ & $\mathbf{2 a}$ & $\mathbf{2 a}$ & $\mathbf{2 b}$ & $\mathbf{2 b}$ & $\mathbf{2 a}$ & $\mathbf{2 a}$ &. & $\mathbf{1}$ & $\mathbf{2 a}$ & $\mathbf{2 a}$ & $\mathbf{V}$ & $\mathbf{I V}$ \\
$\mathbf{1}$ & + & $\mathbf{1}$ & + & $\mathbf{r}$ & $\mathbf{r}$ & + & $\mathbf{I V}$ & + &. & + & + & + & $\mathbf{1}$ & $\mathbf{r}$ &. &. & $\mathbf{r}$ & + & $\mathbf{1}$ & + &. & $\mathbf{I V}$ & $\mathbf{I V}$ \\
$\mathbf{1}$ & $\mathbf{1}$ &. &. & + & + &. & $\mathbf{I I}$ & $\mathbf{1}$ & $\mathbf{1}$ & + & $\mathbf{1}$ & + & $\mathbf{1}$ & + & $\mathbf{1}$ &. & + & $\mathbf{r}$ &. & $\mathbf{1}$ &. & $\mathbf{I V}$ & $\mathbf{I I I}$ \\
\hline
\end{tabular}

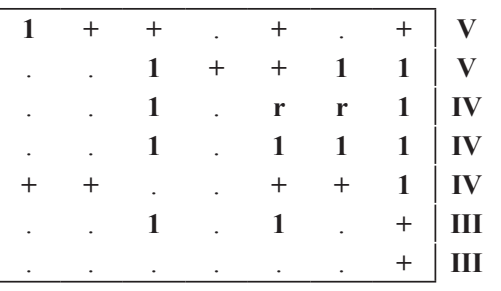

$\begin{array}{cc}\text { III } & \text { IV } \\ \text { II } & \text { IV } \\ \text { II } & \text { III } \\ \text { I } & \text { II } \\ & \text { II } \\ & \text { II } \\ & \text { II }\end{array}$
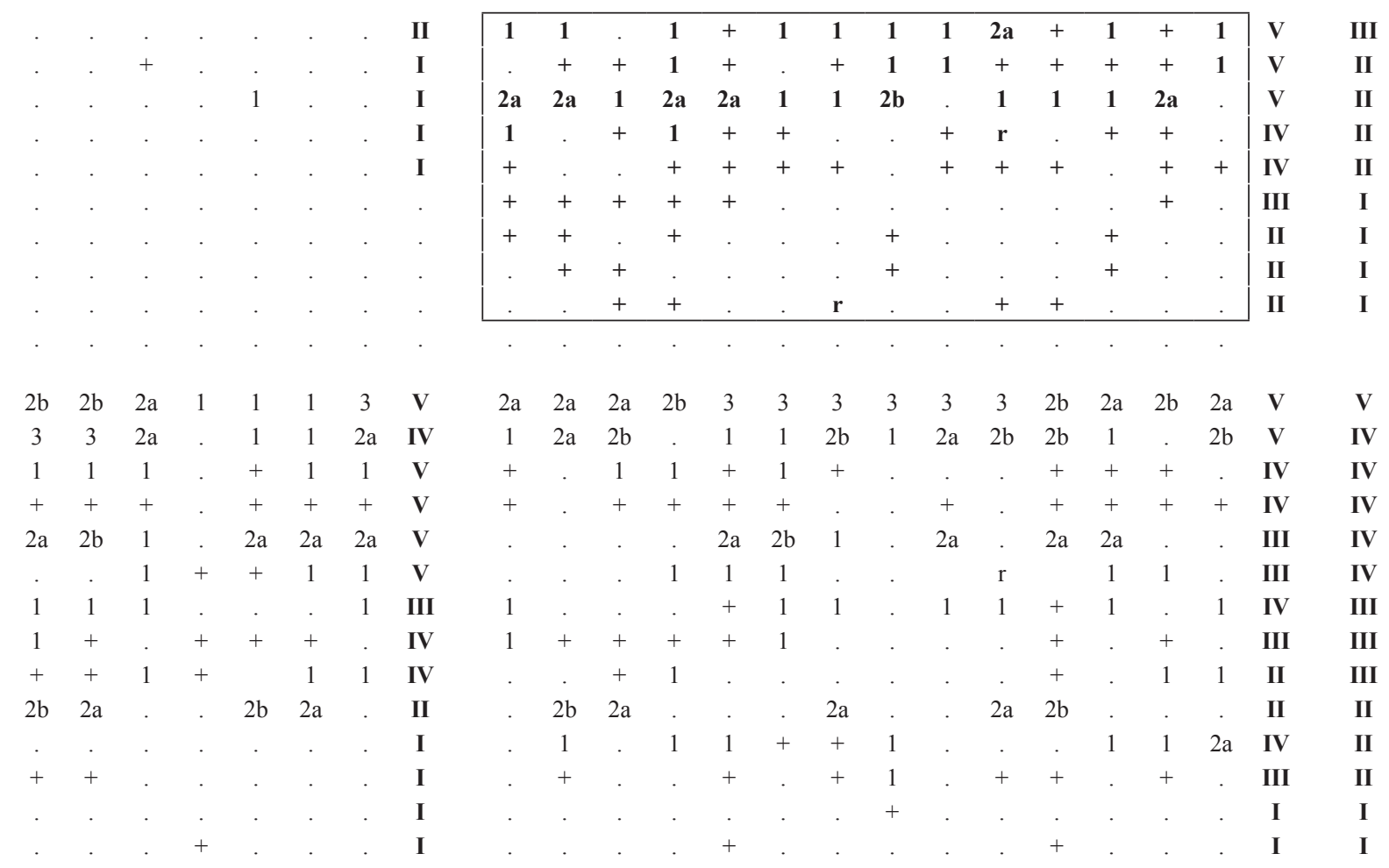


\begin{tabular}{|c|c|c|c|c|c|c|c|c|c|c|c|c|c|c|c|c|}
\hline & & Relevé № & 3 & 11 & 2 & 10 & 1 & 20 & 16 & 17 & 24 & 37 & 27 & 38 & 36 & 31 \\
\hline Eur-Med & $\mathrm{H}$ & Cephalaria flava & . & + & + & . & . & . & . & $\cdot$ & . & . & . & . & . & . \\
\hline Alp-Carp-Bal & $\mathrm{Th}$ & Acinos alpinus & . & + & . & + & + & . & . & + & . & . & . & . & . & . \\
\hline Bal-Anat & $\mathrm{Ch}$ & Micromeria cristata & . & + & . & . & . & . & . & . & . & . & . & . & . & . \\
\hline \multirow[t]{2}{*}{ Eur-As } & $\mathrm{H}$ & Herniaria hirsuta & . & . & . & . & . & . & . & . & . & . & . & . & . & . \\
\hline & & All. Festucion valesiacae Klika 1931 ( $F$. & pic & ae $\mathrm{S}$ & ó 19 & & & & & & & & & & & \\
\hline Pont-Med & $\mathrm{H}$ & Eryngium campestre & . & . & . & . & . & + & 1 & + & + & . & 1 & . & . & . \\
\hline Pont-Med & $\mathrm{Ch}$ & Teucrium polium & . & + & + & + & + & + & 1 & + & + & . & . & . & . & . \\
\hline Eur-As & $\mathrm{H}$ & Medicago falcata ssp. falcata & . & + & . & + & . & . & + & + & + & + & 1 & + & 1 & + \\
\hline subMed & $\mathrm{H}$ & Trinia glauca ssp. glauca & + & . & . & + & . & $\mathrm{r}$ & 1 & 1 & + & . & 1 & + & . & + \\
\hline Eur-As & $\mathrm{H}$ & Galium album ssp. album & . & + & + & . & + & . & . & + & . & . & + & . & . & . \\
\hline Eur-Med & $\mathrm{H}$ & Veronica austriaca & . & + & . & . & . & + & . & . & + & + & 1 & + & . & + \\
\hline Pont-Med & $\mathrm{G}$ & Stipa capillata & . & . & . & . & . & + & . & 1 & . & . & . & + & + & . \\
\hline SPont & $\mathrm{H}$ & Onobrychis arenaria & . & . & . & . & . & . & . & + & + & . & + & + & . & + \\
\hline Med & $\mathrm{H}$ & Scorzonera hispanica & + & . & 1 & . & + & . & . & . & . & . & . & . & . & + \\
\hline Med & $\mathrm{G}$ & Allium flavum & . & + & . & . & . & . & . & . & . & . & . & . & . & . \\
\hline Pont-Med & $\mathrm{G}$ & Chrysopogon gryllus & . & . & . & . & . & . & . & . & . & . & . & . & . & . \\
\hline subMed-As & G & Botriochloa ischaemum & . & . & . & . & $2 \mathrm{a}$ & . & . & $\cdot$ & . & . & . & . & . & . \\
\hline Pont-subMed & $\mathrm{H}$ & Petrorhagia illyrica ssp. haynaldiana & . & . & . & . & . & . & . & . & . & . & . & . & . & . \\
\hline subMed & $\mathrm{H}$ & Potentilla laciniosa & . & . & . & . & . & . & . & . & . & . & . & . & . & . \\
\hline Eur-As & $\mathrm{G}$ & Poa badensis & . & . & . & + & . & . & . & . & + & . & . & + & . & . \\
\hline \multirow[t]{2}{*}{ subMed } & $\mathrm{H}$ & Plantago argentea & . & . & . & . & . & . & . & . & . & + & . & + & . & . \\
\hline & & Ord. Festucetalia valesiacae $\mathrm{Br}$.-Bl. et T & en & 43 & nd $\mathrm{C}$ & $\mathrm{Fe}$ & uco- & rom & tea & r.-Bl & et $\mathrm{Ti}$ & xen 1 & 943 & & & \\
\hline subBoreal & $\mathrm{H}$ & Sanguisorba minor & + & + & + & . & + & + & 1 & + & + & + & 1 & + & + & + \\
\hline subMed & $\mathrm{Ch}$ & Teucrium chamaedrys & . & + & $2 \mathrm{~m}$ & + & + & . & + & 3 & 1 & + & . & + & + & + \\
\hline Eur & $\mathrm{H}$ & Euphorbia cyparissias & . & + & + & + & . & + & + & + & + & + & 1 & + & . & + \\
\hline Pont-Med & $\mathrm{H}$ & Leontodon crispus & 1 & + & + & 1 & + & + & 1 & 1 & . & + & 1 & + & . & 1 \\
\hline Eur-subMed & $\mathrm{H}$ & Asperula cynanchica & . & + & . & + & . & + & + & + & + & . & + & + & + & + \\
\hline Eur-As & $\mathrm{H}$ & Astragalus onobrychis ssp. chlorocarpus & . & . & . & . & + & + & + & . & . & . & . & . & . & + \\
\hline Pont & $\mathrm{G}$ & Koeleria nitidula & 1 & + & . & . & 1 & . & . & 1 & 1 & . & . & 1 & + & . \\
\hline Eur & Th & Cuscuta epithymum & . & $\mathrm{r}$ & . & $\mathrm{r}$ & . & + & . & + & + & + & . & . & + & . \\
\hline Eur-Sib & $\mathrm{G}$ & Fragaria viridis & . & . & . & . & . & . & . & . & . & + & 1 & + & + & . \\
\hline Pont-Med & $\mathrm{H}$ & Linum tenuifolium & + & + & + & . & + & . & . & . & . & + & . & + & + & + \\
\hline subMed & Th & Euphrasia pectinata & + & . & . & + & + & . & + & + & + & + & + & + & . & + \\
\hline Pont-Med & $\mathrm{Ch}$ & Onosma visianii & + & + & . & + & + & . & . & . & . & . & . & . & . & . \\
\hline Pont-Med & $\mathrm{G}$ & Stipa capillata & . & . & . & . & . & + & . & + & . & . & . & + & + & . \\
\hline Pont-Med & $\mathrm{G}$ & Hyacintella leucophaea & 1 & . & . & + & . & . & . & . & . & . & . & . & . & . \\
\hline Eur-Med & $\mathrm{H}$ & Inula oculus-christi & . & . & . & . & . & + & + & + & . & + & . & . & 1 & . \\
\hline Med-OT & $\mathrm{G}$ & Muscari neglectum & . & . & . & . & . & + & . & + & + & . & . & . & . & . \\
\hline subMed & $\mathrm{H}$ & Hippocrepis comosa ssp. comosa & . & . & + & . & . & + & . & . & . & . & . & . & . & + \\
\hline Eur-Med & $\mathrm{H}$ & Filipendula vulgaris & . & . & . & 1 & . & . & . & . & + & . & + & . & + & . \\
\hline subMed & $\mathrm{Ch}$ & Ononis pusilla ssp. orientalis & . & + & + & . & + & . & . & . & . & . & . & + & . & . \\
\hline Eur-Sib & $\mathrm{H}$ & Inula hirta & . & + & . & . & . & . & + & . & . & . & . & . & + & + \\
\hline subMed & $\mathrm{Ch}$ & Hyssopus officinalis ssp. aristatus & 1 & + & . & . & . & . & . & . & . & . & . & . & . & . \\
\hline Kos & $\mathrm{H}$ & Plantago lanceolata & . & . & . & . & . & . & + & . & . & . & + & . & + & . \\
\hline Eur-Med & Th & Carduus nutans & . & . & . & . & $\cdot$ & . & . & $\cdot$ & . & . & . & . & . & . \\
\hline subMed & $\mathrm{Th}$ & Crupina vulgaris & . & + & + & . & . & . & . & . & . & . & . & . & . & . \\
\hline subBoreal & $\mathrm{H}$ & Minuartia verna & . & . & . & $\mathrm{r}$ & . & . & . & . & . & . & . & . & . & . \\
\hline Pont-Med & Th & Thesium dollineri & + & + & . & . & . & . & . & . & + & . & . & . & . & . \\
\hline Kos & $\mathrm{G}$ & Poa pratensis & . & . & . & . & . & . & . & . & . & . & . & . & . & + \\
\hline Ssib & $\mathrm{H}$ & Ajuga laxmannii & . & . & . & . & . & . & . & . & . & + & . & . & + & . \\
\hline Eur-As & $\mathrm{H}$ & Galium verum & . & . & . & . & . & . & . & + & . & . & . & + & . & . \\
\hline subMed & $\mathrm{H}$ & Digitalis lanata & . & . & . & . & . & . & . & . & . & . & . & . & . & . \\
\hline Eur-Med & $\mathrm{H}$ & Inula ensifolia & 1 & . & . & . & + & . & . & . & . & . & . & 1 & . & + \\
\hline Eur-Med & $\mathrm{H}$ & Hieracium bauhinii & . & + & 1 & . & . & . & . & . & . & . & + & . & . & . \\
\hline Eur & $\mathrm{G}$ & Briza media & . & . & . & . & . & . & . & . & . & + & + & + & + & + \\
\hline
\end{tabular}



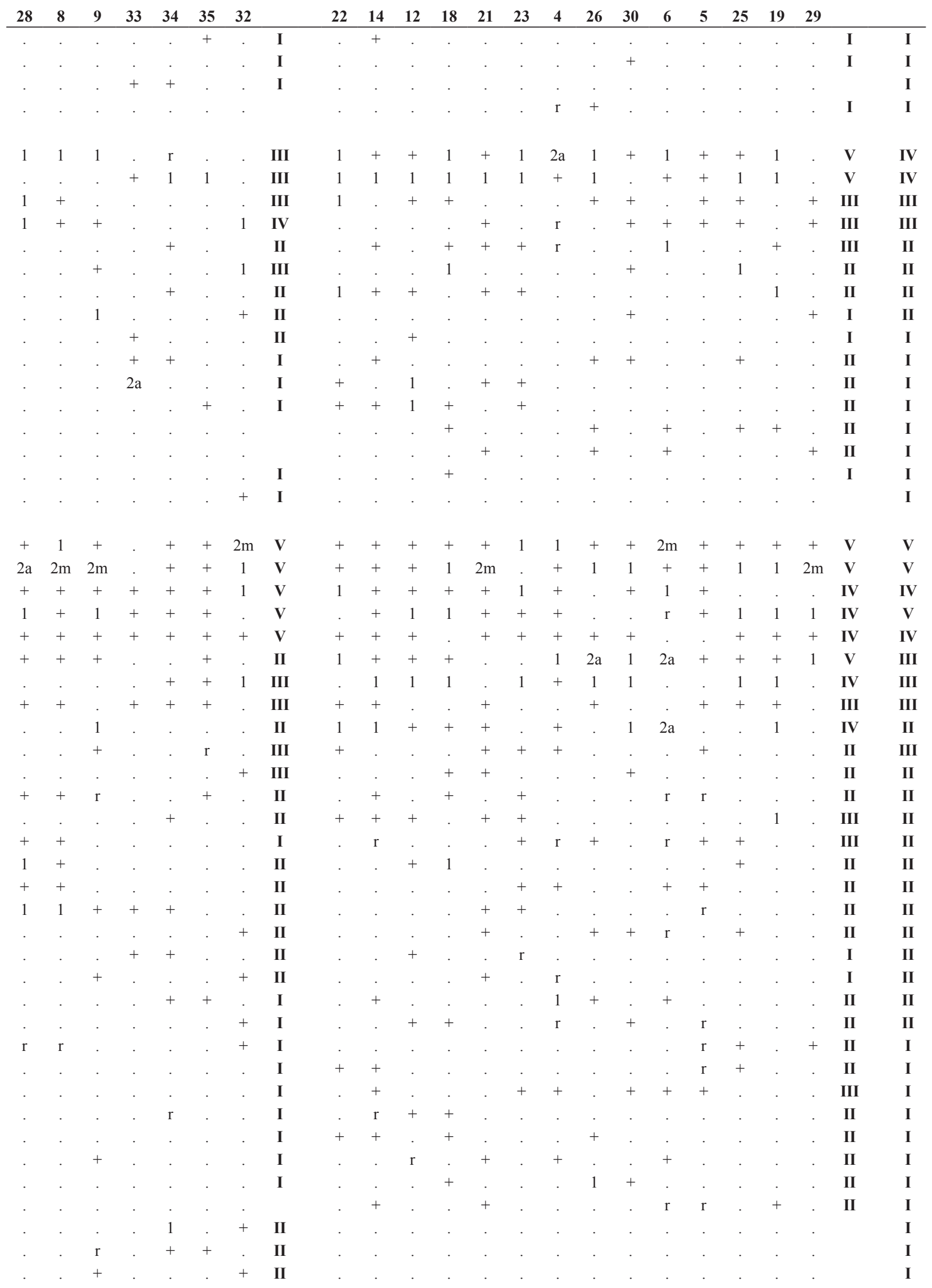


\begin{tabular}{|c|c|c|c|c|c|c|c|c|c|c|c|c|c|c|c|c|}
\hline & & Relevé № & 3 & 11 & 2 & 10 & 1 & 20 & 16 & 17 & 24 & 37 & 27 & 38 & 36 & 31 \\
\hline Eur-subMed & $\mathrm{H}$ & Achillea collina & . & . & . & . & . & . & . & . & . & . & + & + & + & . \\
\hline SEEur & $\mathrm{H}$ & Stachys recta ssp. subcrenata & . & . & . & . & . & . & . & . & . & + & . & . & . & . \\
\hline Kos & $\mathrm{H}$ & Hypericum perforatum & . & . & . & . & + & . & . & . & . & . & . & + & . & . \\
\hline Boreal & $\mathrm{H}$ & Plantago media & . & . & . & + & . & . & . & . & . & . & . & . & . & . \\
\hline Boreal & G & Carex caryophyllea & . & . & . & . & . & . & . & . & . & . & 1 & . & . & . \\
\hline Carp-Bal & $\mathrm{H}$ & Silene flavescens ssp. flavescens & . & $\mathrm{r}$ & + & . & . & . & . & . & . & . & . & . & . & . \\
\hline Bal & $\mathrm{H}$ & Anthyllis aurea & 1 & . & . & . & . & . & . & + & . & . & . & . & . & . \\
\hline Eur & G & Pulsatilla montana & . & . & . & . & . & . & . & . & . & $\mathrm{r}$ & . & . & . & . \\
\hline Eur-As & $\mathrm{H}$ & Origanum vulgare ssp. vulgare & . & + & . & . & . & . & . & . & . & . & . & . & + & . \\
\hline subMed & $\mathrm{Ch}$ & Genista januensis & . & . & 1 & . & 1 & . & . & . & . & . & . & . & . & . \\
\hline Eur-Sib & $\mathrm{H}$ & Centaurea scabiosa & . & . & . & . & . & . & . & . & + & . & . & $\mathrm{r}$ & . & . \\
\hline Med & $\mathrm{H}$ & Polygala anatolica & . & . & . & . & . & . & . & . & . & . & . & . & . & + \\
\hline Bal & G & Sesleria latifolia & . & . & 1 & . & 1 & . & . & . & . & . & . & . & . & 1 \\
\hline Eur-Med & $\mathrm{H}$ & Lotus corniculatus & . & . & . & . & . & . & . & + & . & + & + & . & . & . \\
\hline Pont-subMed & G & Allium moschatum & . & . & . & . & . & . & . & . & . & . & . & . & . & . \\
\hline Bal-Anat & $\mathrm{Ch}$ & Thymus moesiacus & . & . & . & . & . & . & . & . & . & . & . & . & . & . \\
\hline Eur-Med & $\mathrm{H}$ & Trifolium campestre & . & . & . & . & . & . & . & . & . & . & . & . & . & . \\
\hline Eur-Med & $\mathrm{H}$ & Coronilla varia & . & . & . & . & . & . & . & . & . & . & . & . & . & . \\
\hline \multirow[t]{2}{*}{ Pont-subMed } & $\mathrm{H}$ & Orlaya grandiflora & . & . & . & . & . & . & . & . & . & . & . & . & . & . \\
\hline & & Other species & & & & & & & & & & & & & & \\
\hline Bal-Anat & $\mathrm{H}$ & Centaurea affinis ssp. affinis & 1 & . & . & $\mathrm{r}$ & . & + & + & 1 & + & + & 1 & + & + & + \\
\hline Med & $\mathrm{H}$ & Plantago subulata & 1 & . & . & 1 & . & 1 & + & $2 \mathrm{a}$ & + & + & 1 & + & + & + \\
\hline Eur & $\mathrm{H}$ & Orobanche reticulata & . & $\mathrm{r}$ & . & . & . & . & . & + & . & + & . & + & . & . \\
\hline Omed & $\mathrm{H}$ & Asyneuma limonifolium ssp. limonifolium & + & . & . & . & . & . & . & . & . & . & . & . & . & + \\
\hline Eur-Sib & $\mathrm{H}$ & Trifolium alpestre & . & . & . & + & . & . & . & . & . & . & . & . & + & + \\
\hline subBoreal & $\mathrm{Ph}$ & Crataegus monogyna & . & + & + & . & + & . & . & . & + & . & . & + & . & + \\
\hline Med & $\mathrm{H}$ & Euphorbia barrelieri & . & + & 1 & . & + & . & . & . & . & . & . & + & . & + \\
\hline Bal & $\mathrm{H}$ & Hieracium pannosum & . & . & . & + & . & . & . & . & . & + & + & . & + & + \\
\hline subMed & $\mathrm{Ph}$ & Fraxinus ornus & . & . & + & . & 1 & . & . & . & . & . & . & . & . & . \\
\hline Eur-As & $\mathrm{Th}$ & Arabis recta & . & + & . & . & . & . & . & . & . & . & . & . & . & . \\
\hline Med & $\mathrm{H}$ & Euphorbia niciciana & . & . & . & . & . & . & . & . & . & + & . & . & + & . \\
\hline Bal & $\mathrm{H}$ & Minuartia bosniaca & . & . & . & . & . & . & . & . & . & . & . & . & + & + \\
\hline Pont-Cas & G & Elymus hispidus ssp. hispidus & . & + & . & . & + & . & . & . & . & . & . & . & . & . \\
\hline Eur-As & $\mathrm{Th}$ & Medicago minima & . & . & . & . & . & . & . & + & . & . & . & . & . & . \\
\hline Eur-As & Th & Arenaria serpyllifolia & . & . & . & . & . & . & . & . & . & . & . & + & . & . \\
\hline subMed & $\mathrm{Ph}$ & Rosa agrestis & . & . & . & . & . & . & . & . & . & . & . & . & . & . \\
\hline subMed & $\mathrm{Ph}$ & Rosa canina & . & . & . & . & . & $\mathrm{r}$ & . & . & . & . & . & . & . & . \\
\hline Eur-Sib & G & Carex tomentosa & . & . & . & . & . & . & . & . & . & . & . & . & . & . \\
\hline subMed & $\mathrm{Th}$ & Bromus squarrosus & . & . & . & . & . & . & . & . & . & . & . & . & . & . \\
\hline Eur-As & Th & Vicia angustifolia & . & . & . & . & . & . & . & . & . & . & . & . & . & . \\
\hline Pont-Med & Th & Bupleurum commutatum ssp. commutatum & . & . & . & . & . & . & . & . & . & . & . & . & . & . \\
\hline Eur-Med & $\mathrm{H}$ & Trifolium dubium & . & . & . & . & . & . & . & . & . & . & . & . & . & . \\
\hline Eur-subMed & G & Ornithogalum kochii & . & . & . & . & . & . & . & . & . & . & . & . & . & . \\
\hline Kos & $\mathrm{H}$ & Convolvulus arvensis & . & . & . & . & . & . & . & . & . & . & . & . & . & . \\
\hline Bal-Dac & G & Avenula compressa & . & . & . & . & 1 & . & . & . & . & . & . & . & . & . \\
\hline Eur & G & Anthericum ramosum & . & . & . & . & . & . & . & . & . & + & . & + & . & . \\
\hline Eur & $\mathrm{H}$ & Campanula bononiensis & . & $\mathrm{r}$ & . & . & . & . & . & . & $\mathrm{r}$ & . & $\mathrm{r}$ & . & . & . \\
\hline Eur-Sib & $\mathrm{Ph}$ & Cotoneaster integerrimus & . & . & $\cdot$ & . & + & $\cdot$ & $\cdot$ & . & . & . & . & . & . & . \\
\hline Pont-Med & Th & Odontites glutinosa & . & . & . & . & . & . & + & + & . & . & . & . & + & . \\
\hline Eur-subMed & $\mathrm{H}$ & Alyssum murale & . & + & . & . & . & . & . & . & . & . & . & . & . & . \\
\hline Med & $\mathrm{H}$ & Scorzonera cana & . & + & . & . & . & . & . & . & . & . & . & . & . & . \\
\hline Bal & $\mathrm{H}$ & Dianthus moesiacus ssp. moesiacus & . & . & . & . & . & . & . & + & . & . & . & . & . & . \\
\hline Eur & G & Carex michelii & 1 & . & . & . & + & . & . & . & . & . & . & . & . & . \\
\hline Eur-Med & $\mathrm{H}$ & Primula veris & . & . & . & . & . & . & . & . & . & $\mathrm{r}$ & + & . & . & . \\
\hline Eur-Sib & Th & Rhinanthus minor & . & . & . & . & . & . & . & .. & + & . & + & + & . & . \\
\hline
\end{tabular}



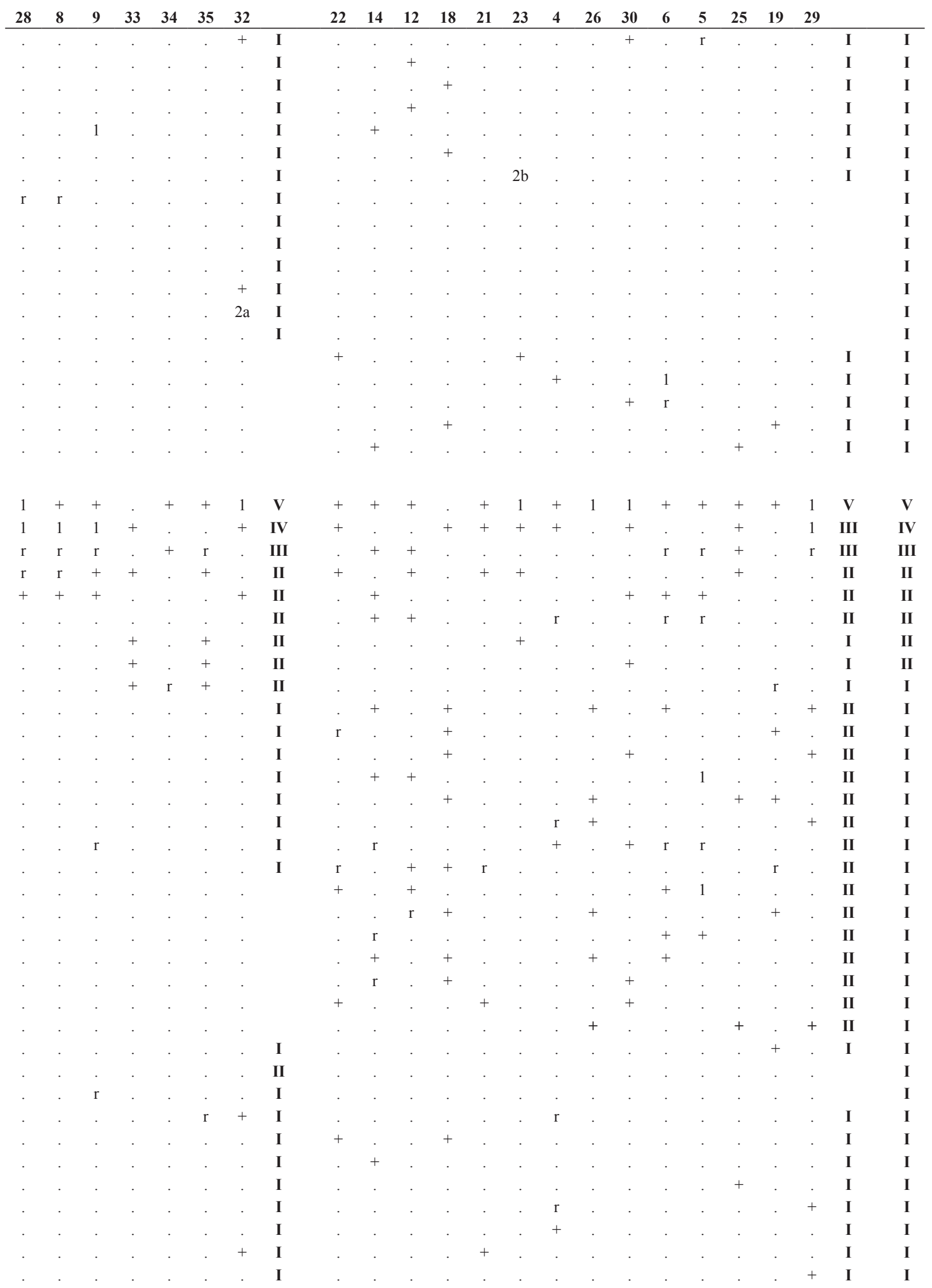


\begin{tabular}{|c|c|c|c|c|c|c|c|c|c|c|c|c|c|c|c|c|}
\hline & & Relevé № & 3 & 11 & 2 & 10 & 1 & 20 & 16 & 17 & 24 & 37 & 27 & 38 & 36 & 31 \\
\hline$\overline{\text { Eur }}$ & & Geranium sanguineum & . & . & + & . & . & . & . & . & . & . & . & . & . & + \\
\hline subBoreal & $\mathrm{Ph}$ & Juniperus communis & . & . & . & . & . & . & . & . & . & . & . & . & + & . \\
\hline Eur-Med & Th & Arabis sagittata & . & . & . & . & . & . & . & . & . & . & . & + & . & . \\
\hline subMed & $\mathrm{Th}$ & Bupleurum sibthorpianum & . & + & . & . & $\cdot$ & . & . & . & + & . & . & . & . & . \\
\hline subMed & $\mathrm{Ph}$ & Coronilla emerus ssp. emeroides & . & $\mathrm{r}$ & 1 & . & . & . & . & . & . & . & . & . & . & . \\
\hline Bal & $\mathrm{Ch}$ & Genista subcapitata & . & . & . & + & . & . & . & . & . & . & . & . & . & . \\
\hline Eur-As & $\mathrm{Ph}$ & Rosa dumalis & . & . & . & . & . & . & . & . & . & $\mathrm{r}$ & $\mathrm{r}$ & . & . & . \\
\hline Med-cAs & & Corylus avellana & . & . & + & . & . & . & . & . & . & . & . & . & . & . \\
\hline Pont-Bal & Th & Trigonella striata & . & . & . & . & . & . & . & . & . & . & . & . & . & . \\
\hline Bal-Dac & $\mathrm{H}$ & Salvia amplexicaulis & . & . & . & . & . & . & . & . & . & . & . & . & . & . \\
\hline subMed & $\mathrm{Th}$ & Trifolium pallidum & . & . & . & . & . & . & . & . & . & . & . & . & . & . \\
\hline Med & G & Allium cupani & . & . & . & . & 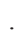 & . & . & . & . & . & . & . & . & . \\
\hline SPont & $\mathrm{Ph}$ & Prunus spinosa & . & . & . & . & . & . & . & . & . & . & . & . & . & . \\
\hline
\end{tabular}

Species that occur only in one relevé: Campanula lingulata 2:+, Pteridium aquilinum 2:2b, Achillea ageratifolia 3:+, Potentilla neglecta 4:r, Medicago lupulina 5:+, Cornus sanguinea 11:+, Helleborus odorus 14:r, Thlaspi alliaceum 14:+, Anthemis ruthenica 17:+, Trigonella monspeliaca 18:+, Cichorium intybus 19:+, Scorzonera mollis 21:+, Verbascum urumovii 21:r, Bupleurum apiculatum 22:+, Medicago coronata 22:+, Euphrasia stricta 23:+, Thymelea passerina 23:+, Ajuga chia 26:+, Phleum montanum 26:+, Centaurea triumfetti ssp. adscendens 27:+, Dianthus cruentus ssp. cruentus 29:+, Prunella laciniata 31:+, Prunella grandiflora 31:+, Danthonia alpina 32:+, Onosma echiodes 33:+, Scabiosa argentea 33:+, Hieracium heterogynum 34:+, Pinus sylvestris 34:r, Paronychia cephalotes 35:+, Rosa elliptica 35:+, Erysimum diffusum 38:+

GPS coordinates and date of the relevés:

1 - N42 2945.5 E23 1144.4 (18.6.2008); 2 - N42 2946.6 E23 1139.2 (18.6.2008); 3 - N42 29 47.1 E23 11 31.9 (18.6.2008);

4 - N42 2952.4 E23 1130.4 (21.6.2008); 5 - N42 29 50.5 E23 1123.5 (23.6.2008); 6 - N42 29 58.4 E23 11 28.5 (23.6.2008);

8 - N42 30 06.2 E23 1135.3 (01.7.2008); 9 - N42 30 12.1 E23 1138.5 (01.7.2008); 10 - N42 30 16.2 E23 11 32.1 (01.7.2008);

11 - N42 29 31.6 E23 1136.1 (01.7.2008); 12 - N42 29 36.1 E23 11 16.6 (04.7.2008); 14 - N42 29 45.3 E23 11 15.8 (04.7.2008);

16 - N42 3026.6 E23 1150.5 (05.7.2008); 17 - N42 30 28.1 E23 12 03.9 (05.7.2008); 18 - N42 29 58.0 E23 10 54.4 (06.7.2008);

19 - N42 30 01.1 E23 1104.8 (06.7.2008); 20 - N42 30 08.9 E23 11 16.2 (06.7.2008); 21 - N42 30 15.3 E23 10 31.5 (07.7.2008);

22 - N42 30 10.6 E23 1034.6 (07.7.2008); 23 - N42 30 17.6 E23 1038.5 (07.7.2008); 24 - N42 31 16.7 E23 11 13.2 (09.7.2008);

25 - N42 3101.8 E23 1059.6 (08.7.2008); 26 - N42 30 58.4 E23 1055.3 (09.7.2008); 27 - N42 3058.0 E23 13 09.1 (09.7.2008);

28 - N42 3045.1 E23 1036.1 (10.7.2008); 29 - N42 30 55.3 E23 12 51.6 (10.7.2008); 30 - N42 30 55.8 E23 12 42.5 (11.7.2008);

31 - N42 3049.2 E23 1230.3 (11.7.2008); 32 - N42 30 51.1 E23 12 18.1 (11.7.2008); 33 - N42 29 49.2 E23 10 19.2 (12.7.2008);

34 - N42 29 33.5 E23 1121.4 (12.7.2008); 35 - N42 29 53.4 E23 1148.8 (12.7.2008); 36 - N42 3044.5 E23 13 33.6 (13.7.2008);

37 - N42 3037.9 E23 1326.1 (13.7.2008); 38 - N42 3012.7 E23 1318.1 (13.7.2008); 


\begin{tabular}{|c|c|c|c|c|c|c|c|c|c|c|c|c|c|c|c|c|c|c|c|c|c|c|c|}
\hline 28 & 8 & 9 & 33 & 34 & 35 & 32 & & 22 & 14 & 12 & 18 & 21 & 23 & 4 & 26 & 30 & 6 & 5 & 25 & 19 & 29 & & \\
\hline . & . & . & . &. &. & $\cdot$ & I &. & + & $\cdot$ & . & . & . & . & . & . & . & . & . & . & . & I & I \\
\hline . & . & . & . & . & . & . & I & . & . & . & . & . & . & . & . & . & . & $\mathrm{r}$ & . & . & . & I & I \\
\hline . & . & . & . & . & . & + & I & . & . & . & 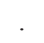 & . & . & . & . & . & . & . & . & . & . & . & I \\
\hline . & . & . & . & . & . & . & I & . & . & . & 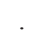 & . & . & . & . & . & . & . & . & . & . & . & I \\
\hline . & . & . & . & . & . & . & I & . & . & . & . & . & . & . & . & . & . & . & . & . & . & . & I \\
\hline . & . & . & + & . & . & . & I & . & . & . & . & . & . & . & . & . & . & . & . & . & . & . & I \\
\hline $\mathrm{r}$ & $\mathrm{r}$ & . & . & . & . & . & I & . & . & . & . & . & . & . & . & . & . & . & . & . & . & . & I \\
\hline . & . & . & . & . & $\mathrm{r}$ & . & I & . & . & . & 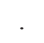 & . & . & . & . & . & . & . & . & . & . & . & I \\
\hline . & . & . & . & . & . & . & & . & + & + & . & . & . & . & . & . & . & . & . & . & . & I & I \\
\hline . & . & . & . & . & . & . & & . & . & . & + & . & . & . & . & + & . & . & . & . & . & I & I \\
\hline . & . & . & . & . & . & . & & . & . & . & + & . & . & . & . & . & . & . & . & + & . & I & I \\
\hline . & . & . & . & . & . & . & & . & . & . & 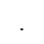 & . & . & . & . & . & 1 & . & + & . & . & I & I \\
\hline . & . & . & . & . & . & . & & . & + & + & . & . & . & . & . & . & . & . & . & . & . & I & I \\
\hline
\end{tabular}

Table 2: Diagnostic species and species with high constancy in the associations of the steppe vegetation in E Serbia and SW Bulgaria.

Tabela 2: Diagnostične vrste in vrste $\mathrm{z}$ visoko prisotnostjo v asociacijah stepske vegetacije vzhodne Srbije in jugozahodne Bolgarije.

Cl. Festuco-Brometea Br.-Bl. et Tüxen 43

Ord. Festucetalia valesiacae Br.-Bl. et Tüxen 43

All. Saturejon montanae Horvat 62

BS - Bromo moesiacae-Stipetum epilosae ass. nova from Bosnek karstic region, SW Bulgaria

MIs - Myrsiniteto-Ischaemetum R. Jov. 55 from Suva Mt, Serbia

HSr - Humileto-Stipetum pulcherrimae (=grafianae) R. Jov. 55 from Rtanj Mt, Serbia

HSs - Humileto-Stipetum pulcherrimae (=grafianae) R. Jov. 55 from Suva Mt, Serbia

Sjr - Stipetum joannis (=tirsae) R.Jov. 56 from Rtanj Mt, Serbia

$\mathrm{PCr}$ - Potentilleto-Caricetum humilis R.Jov. 55 from Rtanj Mt, Serbia

PCs - Potentilleto-Caricetum humilis R.Jov. 55 from Suva Mt, Serbia

HS - Hypericum rochelii-Stipetum epilosae Ped. et al. 2009 from Lozenska Mt, SW Bulgaria

* - species that are locally characterstic for the associations (Jovanović-Dunjić 1955, 1956)

1-5 - Constancy classes

\begin{tabular}{|c|c|c|c|c|c|c|c|c|}
\hline & BS & MIs & $\mathrm{HSr}$ & HSs & Sjr & $\mathrm{PCr}$ & $\mathrm{PCs}$ & HS \\
\hline Hypericum rumeliacum & 5 & . & . & . & . & . & . & . \\
\hline Pimpinella tragium ssp. lithophila & 5 & . & . & . & . & . & . & . \\
\hline Thymus striatus & 5 & . & . & . & . & . & . & 3 \\
\hline Stipa epilosa & 5 & . & . & . & . & . & . & 4 \\
\hline Asphodeline taurica & 4 & . & . & . & . & . & . & . \\
\hline Bromus moesiacus & 4 & . & . & . & . & . & . & . \\
\hline Tragopogon balcanicus & 3 & . & . & . & . & . & . & . \\
\hline Galium purpureum (=Asperula purpurea) & 4 & 4 & 5 & 5 & 5 & 3 & . & 3 \\
\hline Artemisia alba & 2 & 5 & $4^{*}$ & 4 & 2 & 1 & . & . \\
\hline Potentilla cinerea & 3 & 4 & 2 & 5 & . & $5 *$ & $5^{*}$ & 5 \\
\hline Asperula cynanchica & 4 & 4 & 2 & 4 & . & 2 & 5 & 4 \\
\hline Carex humilis & 4 & . & 5 & 5 & 5 & $5 *$ & 5 & 4 \\
\hline Galium album ssp. album & 2 & . & 3 & 4 & 3 & 4 & 4 & . \\
\hline Achillea clypeolata & 2 & 3 & 2 & 4 & . & $4 *$ & . & . \\
\hline Stachys recta & 1 & 3 & 4 & 4 & . & 4 & 1 & . \\
\hline
\end{tabular}




\begin{tabular}{|c|c|c|c|c|c|c|c|c|}
\hline & BS & MIs & $\mathrm{HSr}$ & HSs & Sjr & $\mathrm{PCr}$ & PCs & HS \\
\hline Teucrium chamaedrys & 5 & 3 & 5 & 5 & 5 & 4 & . & 2 \\
\hline Stipa pulcherrima & . & 2 & $5^{*}$ & $5^{*}$ & . & . & 5 & . \\
\hline Leontodon crispus & 5 & 2 & 5 & $4 *$ & . & . & 1 & 4 \\
\hline Teucrium montanum & 3 & . & $4^{*}$ & $4^{*}$ & 1 & 1 & 1 & 2 \\
\hline Rosa pimpinellifolia (= Rosa myriacantha) & 1 & . & 4 & 4 & 1 & 3 & 3 & . \\
\hline Cynanchum vincetoxicum (=Vincetoxicum hirundinaria) & 1 & 5 & $4 *$ & $4^{*}$ & 1 & 3 & . & . \\
\hline Sedum ochroleucum & . & 3 & 5 & 4 & . & 5 & 1 & . \\
\hline Bromus erectus & . & . & 2 & 4 & . & 5 & 1 & 1 \\
\hline Chamaecytisus ciliatus & . & . & 5 & 4 & . & 5 & 3 & . \\
\hline Euphorbia cyparissias & 4 & 2 & 5 & 2 & 4 & 4 & 3 & 4 \\
\hline Agropyron cristatum & . & . & $4^{*}$ & 2 & . & . & . & . \\
\hline Satureja montana ssp. kitaibelii & 4 & 4 & $5 *$ & 4 & 1 & 2 & . & 3 \\
\hline Melica ciliata & 2 & $5^{*}$ & 2 & 3 & . & . & . & 1 \\
\hline Botriochloa ischaemum (=Dichantium ischaemum) & 1 & $5^{*}$ & . & . & . & . & . & 1 \\
\hline Allium flavum & 1 & 5 & . & 2 & . & 1 & . & 1 \\
\hline Euphorbia myrsinites & . & $5^{*}$ & . & . & . & . & . & . \\
\hline Teucrium polium & 4 & 4 & . & . & . & . & . & 3 \\
\hline Fumana procumbens & 3 & $4^{*}$ & . & . & . & . & . & 2 \\
\hline Sedum acre & 2 & 4 & . & . & . & . & . & 2 \\
\hline Silene flavescens & 1 & 4 & . & . & . & . & . & . \\
\hline Allium moschatum & 1 & $4^{*}$ & . & . & . & . & . & . \\
\hline Siliene flavescens & 1 & 4 & . & . & . & . & . & . \\
\hline Adonis vernalis & . & 4 & . & . & . & . & . & . \\
\hline Chamaecytisus jankae & . & $4^{*}$ & . & . & . & . & . & . \\
\hline Haplophyllum suaveolens & . & $2 *$ & . & . & . & . & . & $\cdot$ \\
\hline Centaurea biebersteinii ssp. australis & . & $2^{*}$ & . & . & . & . & . & . \\
\hline Cephalaria laevigata & . & . & . & . & . & $4 *$ & . & . \\
\hline Iris reichenbachii & . & . & . & . & . & $4 *$ & . & . \\
\hline Ferulago campestris & . & . & 2 & . & . & $4 *$ & . & . \\
\hline Micromeria cristata & 1 & . & . & $4 *$ & . & . & . & . \\
\hline Cotoneaster tomentosa & . & . & . & 4 & . & . & . & . \\
\hline Amelanchier vulgaris & . & . & . & 4 & . & . & . & . \\
\hline Rhamnus saxatilis & . & . & . & 4 & . & . & 1 & . \\
\hline Achnatherum calamagrostis & . & . & . & 5 & . & . & . & . \\
\hline Achillea ageratifolia & 1 & . & . & 2 & . & . & . & . \\
\hline Aethionema saxatile & . & . & . & $2 *$ & . & . & . & $\cdot$ \\
\hline Stipa joannis & . & . & 5 & . & $5^{*}$ & . & . & $\cdot$ \\
\hline Scleranthus annuus & . & . & . & . & $4^{*}$ & . & . & $\cdot$ \\
\hline Herniaria hirsuta & 1 & . & . & . & $4^{*}$ & . & . & . \\
\hline Bromus mollis (B. hordeaceus ssp. hordeaceus) & . & . & . & . & $4^{*}$ & . & . & . \\
\hline Alyssum alyssoides & 2 & . & 4 & . & $4^{*}$ & 5 & . & . \\
\hline Koeleria gracilis & . & . & 5 & . & 1 & 5 & 4 & . \\
\hline Thymus glabrescens & . & . & . & 3 & 2 & 1 & 4 & . \\
\hline Centaurea triumfettii & . & . & 5 & . & . & 1 & 5 & . \\
\hline Cotoneaster integerrimus & 2 & . & . & 3 & . & 2 & 5 & . \\
\hline Geranium sanguineum & 2 & . & 3 & . & . & 3 & 4 & . \\
\hline Festuca panciciana & . & . & 5 & 2 & 4 & 4 & 4 & . \\
\hline Veronica jacquinii (=Veronica austriaca ssp. austriaca) & 2 & . & 4 & 2 & 4 & 4 & 4 & . \\
\hline Scabiosa columbaria & . & . & 2 & 2 & 4 & 4 & 4 & . \\
\hline Asyneuma canescens & . & . & 2 & 1 & . & 2 & $3 *$ & 2 \\
\hline Poa badensis & 1 & . & 2 & 2 & . & 2 & 2 & . \\
\hline
\end{tabular}




\begin{tabular}{|c|c|c|c|c|c|c|c|c|}
\hline & $\mathrm{BS}$ & MIs & $\mathrm{HSr}$ & HSs & Sjr & $\mathrm{PCr}$ & $\mathrm{PCs}$ & HS \\
\hline Pulsatilla vulgaris ssp. grandis & . & . & . & . & . & $2 *$ & $4 *$ & . \\
\hline Crocus biflorus & . & . & . & . & . & . & $4 *$ & . \\
\hline Dianthus petraeus & . & . & . & 3 & . & . & 4 & . \\
\hline Trifolium alpestre & 2 & . & . & . & . & . & 4 & . \\
\hline Hypericum linaroides & . & . & . & 1 & . & . & 4 & . \\
\hline Anthyllis montana ssp. jaquinii & . & . & . & . & . & . & 4 & . \\
\hline Helianthemum nuтmularium & . & . & . & . & . & . & . & 5 \\
\hline Muscari botryoides & . & . & . & . & . & . & . & 5 \\
\hline Seseli peucedanoides & . & . & 2 & . & . & 2 & 3 & 4 \\
\hline Sesleria latifolia & 1 & . & . & . & . & . & . & 3 \\
\hline Thesium divaricatum & . & . & . & . & . & . & . & 3 \\
\hline Hypericum rochelii & . & . & 2 & . & . & . & . & 3 \\
\hline Hippocrepis comosa & 2 & . & . & . & . & . & . & 3 \\
\hline Genista tinctoria & . & . & . & . & . & . & . & 2 \\
\hline All. Saturejon montanae Horvat 1962 & . & . & . & . & . & . & . & . \\
\hline Anthyllis vulneraria & 3 & . & . & . & . & . & . & 3 \\
\hline Festuca dalmatica & 5 & . & . & . & 1 & 1 & . & 5 \\
\hline Rhodax canus & 4 & . & . & . & . & . & . & 2 \\
\hline \multicolumn{9}{|c|}{ All. Festucion valesiacae Klika 1931 (F. rupicolae Soó 1940) } \\
\hline Eryngium campestre & 4 & . & . & . & . & . & . & 3 \\
\hline Medicago falcata & 3 & 5 & . & . & . & . & . & 3 \\
\hline Trinia glauca & 3 & . & 5 & . & 1 & 2 & 5 & 2 \\
\hline Plantago argentea & 1 & . & 5 & . & 3 & 3 & 3 & . \\
\hline
\end{tabular}

Ord. Festucetalia valesiacae Br.-Bl. et Tüxen 1943 and Cl. Festuco-Brometea Br.-Bl. et Tüxen 1943

Sanguisorba minor

Plantago lanceolata

Minuartia verna ssp. collina

Lotus corniculatus

Achillea collina

Orlaya grandiflora

Koeleria nitidula

Sideritis montana

Astragalus onobrychis ssp. chlorocarpus

Cuscuta epithymum

Linum tenuifolium

Origanum vulgare ssp. vulgare

\section{Other species}

Calamintha alpina (=Acinos alpinos)

Erysimum diffusum

Achillea crithmifolia

Arenaria serpyllifolia

Minuartia caespitosa

Scabiosa triniifolia

Centaurea affinis ssp. affinis

Globularia aphyllanthes

Carlina acanthifolia

Plantago subulata

Dorycnium herbaceum

Corylus colurna

Primula veris

Corothamnus procumbens (Cytisus procumbens)

\begin{tabular}{|c|c|c|c|c|c|c|}
\hline 5 & 3 & 5 & 2 & 4 & 3 & 1 \\
\hline 2 & . & . & . & 5 & . & 1 \\
\hline 1 & . & 2 & 2 & 4 & 1 & 2 \\
\hline 1 & . & 2 & 1 & 3 & 1 & 1 \\
\hline 1 & . & 5 & . & 4 & . & . \\
\hline 1 & . & 3 & 4 & . & . & . \\
\hline 3 & . & . & . & . & . & . \\
\hline 3 & . & . & . & . & . & . \\
\hline 3 & . & . & . & . & . & . \\
\hline 3 & . & . & . & . & . & . \\
\hline 3 & . & . & . & . & . & . \\
\hline 1 & . & 3 & . & . & . & . \\
\hline . & $\cdot$ & $\cdot$ & . & . & . & . \\
\hline 1 & $\cdot$ & 5 & 3 & . & 4 & 3 \\
\hline 1 & 2 & . & 2 & 3 & 2 & . \\
\hline 1 & 2 & 3 & . & . & . & . \\
\hline 1 & . & 4 & 3 & 4 & 2 & 1 \\
\hline . & . & . & . & . & . & . \\
\hline 4 & . & . & . & . & . & . \\
\hline 5 & . & . & . & . & . & . \\
\hline 4 & $\cdot$ & . & . & . & . & . \\
\hline 3 & . & . & . & . & . & . \\
\hline 4 & . & . & . & . & . & . \\
\hline 3 & . & $\cdot$ & . & $\cdot$ & . & . \\
\hline 1 & $\cdot$ & . & 4 & . & . & . \\
\hline 1 & $\cdot$ & 2 & . & . & 3 & . \\
\hline . & . & . & 1 & . & 5 & 3 \\
\hline
\end{tabular}




\begin{tabular}{|c|c|c|c|c|c|c|c|c|}
\hline & BS & MIs & $\mathrm{HSr}$ & HSs & Sjr & $\mathrm{PCr}$ & PCs & HS \\
\hline Cerastium banaticum & . & . & 4 & . & . & 4 & 3 & . \\
\hline Senecio rupestris & . & . & 2 & . & 5 & 3 & 3 & . \\
\hline Thymus jankae & . & . & 5 & . & . & 1 & 2 & . \\
\hline Silene sendtneri & . & . & 5 & . & . & 1 & 2 & . \\
\hline Arabis nova & . & . & 4 & . & 4 & . & 1 & . \\
\hline Viola tricolor ssp. macedonica & . & . & 2 & . & 3 & 4 & 5 & . \\
\hline Dorycnium germanicum & . & . & 5 & 1 & . & 2 & 1 & . \\
\hline Dianthus pelviformis & . & . & 2 & . & . & 4 & . & . \\
\hline Centaurea stoebe & . & 4 & . & . & . & . & . & 1 \\
\hline Festuca valesiaca & . & . & 2 & 2 & 5 & . & . & . \\
\hline Calamintha acinos $(=$ Acinos arvensis $)$ & . & 2 & 4 & . & 4 & . & . & . \\
\hline Thymus humifusus (= Thymus praecox) & . & . & . & 5 & 3 & . & . & . \\
\hline Thymus marschalianus (=Thymus pannonicus) & . & 2 & 2 & 4 & 1 & 4 & . & . \\
\hline Jurinea mollis & . & . & 5 & . & . & 2 & . & . \\
\hline Carpinus orientalis & . & 3 & . & . & . & . & . & . \\
\hline Cotoneaster nebrodensis & . & . & . & 4 & . & . & 1 & . \\
\hline Dianthus capitatus & . & . & . & . & . & . & 3 & . \\
\hline Dianthus pelviformis & . & . & 2 & . & . & 4 & . & . \\
\hline Hieracium hoppeanum & . & . & . & 2 & . & . & 3 & . \\
\hline Marrubium peregrinum & . & 3 & . & . & . & . & . & . \\
\hline Mercurialis ovata & . & . & . & 1 & . & 4 & . & . \\
\hline Potentilla argentea & . & . & . & . & 4 & . & . & . \\
\hline Pyrus amygdaliiformis & . & 3 & . & . & . & . & . & . \\
\hline Ranunculus illyricus & . & . & . & . & 2 & 3 & . & . \\
\hline Rumex acetosella & . & . & . & . & 5 & . & . & . \\
\hline Sesleria rigida & . & . & . & 1 & . & 2 & 3 & . \\
\hline Sorbus mougeotii & . & . & . & 3 & . & . & . & . \\
\hline Stachys officinalis & . & . & . & . & . & 1 & 3 & . \\
\hline Syringa vulgaris & . & . & 3 & 3 & . & . & . & . \\
\hline Veratrum nigrum & . & . & 3 & . & 4 & 1 & . & . \\
\hline Viola macedonica & . & . & 2 & . & 3 & 4 & . & . \\
\hline
\end{tabular}

